University of California, Hastings College of the Law UC Hastings Scholarship Repository

Faculty Scholarship

1961

\title{
Indispensable Party: The Historical Origin of a Procedural Phantom
}

Geoffrey C. Hazard Jr.

UC Hastings College of the Law, hazardg@uchastings.edu

Follow this and additional works at: http://repository.uchastings.edu/faculty_scholarship

\section{Recommended Citation}

Geoffrey C. Hazard Jr., Indispensable Party: The Historical Origin of a Procedural Phantom, 61 Colum. L. Rev. 1254 (1961). Available at: http://repository.uchastings.edu/faculty_scholarship/937

This Article is brought to you for free and open access by UC Hastings Scholarship Repository. It has been accepted for inclusion in Faculty Scholarship by an authorized administrator of UC Hastings Scholarship Repository. For more information, please contact marcusc@uchastings.edu. 


\section{Faculty Publications \\ UC Hastings College of the Law Library}

Author: Geoffrey C. Hazard, Jr.

Source: $\quad$ Columbia Law Review

Citation: $\quad 61$ Colum. L. Rev. 1254 (1961).

Title: $\quad$ Indispensable Party: The Historical Origin of a Procedural Phantom

Originally published in COLUMBIA LAW REVIEW. This article is reprinted with permission from COLUMBIA LAW REVIEW and Columbia University School of Law. 


\title{
INDISPENSABLE PARTY: THE HISTORICAL ORIGIN OF A PROCEDURAL PHANTOM $†$
}

\author{
GEOFFREY C. HAZARD, JR.*
}

In spite of the vast number of cases that have arisen concerning who are necessary and who are indispensable parties, the governing principles have remained comparatively simple and constant . ... "Persons who not only have an interest in the controversy, but an interest of such a nature that a final decree cannot be made without either affecting that interest, or leaving the controversy in such a condition that its final termination may be wholly inconsistent with equity and in good conscience" are indispensable . ... Unless the absence of an indispensable party can be and is cured by his joinder, dismissal must be granted. ${ }^{1}$

Conventional procedural terminology divides parties to litigation into four general categories: "improper" parties, "proper" parties, "necessary" parties, and "indispensable" parties. ${ }^{2}$ Application of the rule embodied in the first three categories is today rarely the subject of practical or analytical difficulty. An improper party is one whose relation to the controversy is so remote that he ought not to be in court; a proper party is one whose relation to the controversy is such that he may appropriately be brought into the litigation but whose absence will occasion no concern; a necessary party is one whose relation to the controversy is such that in the interests of orderly and consistent judicial administration he should be brought in if at all possible. ${ }^{3}$

The indispensable party concept, however, has occasioned much confusion in the cases. According to conventional doctrine, an indispensable party is one whose relationship to the controversy is so imnediate and so intimate that the court is said to be unable to proceed without him. ${ }^{4}$ The crucial difference between a necesary and an indispensable party is said to be this: if a necessary party cannot be brought before the court for one reason or another (for example, because he is outside the territorial limits to which the court's process runs), the court may nevertheless proceed to dispose of the controversy as best it can. On the other hand, if a party is indispensable

$\dagger$ This article is based in part on an address given before the annual meeting of the Pacific Coast Branch of the American Society for Legal History, held at the University of California Law School, Los Angeles, September 24, 1960.

* Professor of Law, University of California, Berkeley.

1. 3 Moore, Federal Practice f 19.07, at 2150, 2152 (2d ed. 1953).

2. See Clark, Code Pleading 358-62, 365-67, 380-86 (2d ed. 1947).

3. Ibid.

4. The rule is embodied in code pleading provisions, e.g., Car. Cone C1v. Proc. \$ 389; N.Y. Crv. Prac. Act \$ 193, in the federal rules, see FEd. R. Crv. P. 19(b) ("When persons who are not indispensable ... have not been made parties .... the court shall order them summoned ..."), $12(\mathrm{~h})$ ("A party waives all defenses . . which he does not present either by motion ... or . . answer ... except ... the defense of failure to join an indispensable party ..." ), and in state rules modeled on the federal rules, see, e.g., Iowa R. Civ. Proc. 25. 
and is not amenable to process, the court must refuse to adjudicate; it is said to lack jurisdiction in the absence of the indispensable party. Thus does this ghostly character haunt the halls of justice, an apparition whose suggested existence stays the hand of the law.

Professor John Reed has made an admirable analysis of the indispensable party rule, laying bare the logical and practical fallacies that underlie the jurisdictional theory of indispensability. ${ }^{5}$ As he points out, the fallacy lies in the assumption that because the court does not have jurisdiction over the absentee, it can not act with respect to those before it. ${ }^{6}$ Again as Professor Reed points out, this idea is just plain nonsense.

Ordinarily courts do not espouse nonsensical ideas; certainly they do not do so advertently. Where, then, did this strange idea of indispensability originate? Professor Reed has traced the development of the doctrine from the earliest United States Supreme Court cases, through the leading 1854 case of Shields $v$. Barrowes, ${ }^{7}$ down to its present applications. It is the purpose of this article to explore the earlier history of the rules governing parties to equity suits in order to show the background of procedural law against which the indispensable party rule emerged. This analysis will cover the period between the emergence of "modern equity" in the latter part of the seventeenth century and the reception of developed equity procedure by American courts in the early nineteenth century.

During the seventeenth and eighteenth centuries, Chancery developed fairly workable necessary party rules, with exceptions designed to meet practical convenience and necessity. These rules may be summarized as follows:

1. All persons who are interested in a controversy are necessary parties to a suit involving that controversy, so that a complete disposition of the dispute may be made.

2. Joinder of necessary parties is excused when it is impossible, impractical, or involves undue complications.

3. A person who is not a party, unless represented by one who is a party, is not bound by a decree. 483 (1957).

5. Reed, Compulsory Joinder of Parties in Civil Actions, 55 MrcH. L. Rev. 327,

6. Id. at 330-35. Following the suggestion of Professor Paul Hays, see Hays, Teachers' Manual for Cases and Materials on Civil Procedure 16 (1948), Reed demonstrates that the jurisdictional theory of indispensability involves the following reasoning: " $A$ [the absentee] cannot be bound by a court's judgment if he is not properly before the court; $A$ is not before the court; $A$ would be bound by the court's judgment in this case; therefore, no judgment can be rendered. Plainly, there are two inconsistent assertions in the series. If $A$ camnot be bound by a court's judgment in his absence, he will not be bound by the court's judgment in this case." Reed, supra note 5 , at 333 . For illustrative cases involving precisely this contradiction, see Fouke v. Schenewerk, 197 F.2d 234 (5th Cir. 1952); United States v. Fried, 183 F. Supp. 371 (E.D.N.Y. 1960). For an earlier comment pointing out the contradiction, see Note, Indispensable and Necessary Parties, 29 Calm. L. Rev. 731 (1941).

7. 58 U.S. (17 How.) 130 (1854). 
In about 1780 and the three decades that followed, a confused series of opinions were rendered which attempted to establish an additional rule: no decree that does not completêly dispose of the controversy will be entered. Upon this rule is founded the indispensable party notion. It was conceived in dictum and lives by inertia. It should long since have been laid to rest.

\section{The Necessary Party Rule in the Late Seventeente Century- LORD NOtTINGHaM}

Analysis of the early cases dealing with necessary parties may begin with those decided in the time of Lord Nottingham, Lord Keeper and Lord Chancellor of England from 1673 to 1682. This seems appropriate for several reasons. Nottingham presided in Chancery at the time of its emergence from the shadow of the Interregnum and during the completion of its transition from administrative repository of the royal prerogative to judicial tribunal in the modern sense. ${ }^{8}$ Further, Nottingham himself sought to systematize the rules of equity, both substantive and procedural, and is rightly called the "father of systematic equity." Finally, it is only with Nottingham that a significant number of decisions begin to be reported and reliance is regularly placed on precedent-essential conditions for the firm development of doctrine, procedural or substantive. ${ }^{10}$

Nottingham's decisions are available in two sources: the rather fragmentary reports printed in the eighteenth century, ${ }^{11}$ and Nottingham's own manuscript of notes on cases, which was recently published by the Selden Society. ${ }^{12}$ Because of the remarkable similarity of Nottingham's cases to present day cases in regard to the parties problems posed and the solutions developed, it seems desirable to give some account of his decisions.

8. See 5 Holdsworth, Hustory of English Law 217-18, 299-303 (1924) [hereinafter cited as HoldSWORTH]; 6 id. at 523-38.

9. Yale, Introduction, 73 'SELDEN SocIETy, NotrTngham's Chancery CaSes xlv (Yale ed. 1957) [hereinafter cited as 73 Seld. Soc'y]. See also 6 Holdsworth 539-48.

10. Yale, Introduction, 73 Seld. Soc'y xxxvii-1i.

11. See 6 HoLDSWORTH 542, 616-19.

12. See note 9 supra.

It is difficult to assess the respective importance as eighteenth century precedent of the cases in the printed reports as opposed to those reported in Nottingham's manuscript. Of course, the contents of Nottingham's private manuscript, not published until the twentieth century, could not have served as precedent in the eightecnth. However, the first eighteenth century publication of the reports of Nottingham's decisions appeared in 1725 and only as that century wore on were more reports published. Sce Yale, Introduction, 73 Seld. Soc'y xliv. For want of published precedents, practitioners and judges apparently relied on what could be found by poring over the decree and order books of the court. Ibid. By this means many lawyers may and some must liave come upon the cases that Nottingham had discussed in his manuscript. Hence, it is quite possible that the materials on which Nottingham relied for his manuscript, and not the cases in the printed reports, constituted the precedents from which eighteenth century law developed. This was almost certainly the case prior to 1725 , For present purposes the question is largely moot, however, for the cases dealing with partics problems in the printed reports and those in Nottingham's manuscript are substantially the same in approach and doctrine. 
As a general rule, Nottingham recognized that all persons having an interest in the controversy ought to be parties. ${ }^{13}$ Thus, joint obligees should join as plaintiffs ${ }^{14}$ and joint obligors should be joined as defendants ${ }^{15}$ in suits to enforce joint obligations; in a suit by a bond surety to compel the creditor to assign the bond to the surety so that he can indemnify himself against the principal, the principal should be joined $;^{16}$ all holders of interests in a common should be joined in a bill to establish an enclosure $;^{17}$ in a suit to obtain an undivided fractional interest in a block of the shares of a company, all owners of portions of the block should be joined $;^{18}$ and in a bill for accounting against a bankrupt, the bankrupt's assignees in bankruptcy should be joined.19 Again, in a bill for an accounting and payment of the share of a deceased member of a mercantile venture, all members of the venture should be made parties; ${ }^{20}$ and in a bill by legatees claiming a right to the residue of an estate, all persons interested in the estate should be parties. ${ }^{21}$ In these cases, Nottingham did not rely on the indispensability doctrine. On the contrary, he relied on practical considerations of fairness and expediencyavoidance of a multiplicity of actions, ${ }^{22}$ assurance of adequate presentation of

13. Not directly relevant but nevertheless interesting is a case presenting what today would be called a permissive joinder problem. In Stamford v. Aldrich, 73 Seld. Soc'y 403 (No. 543) (Ch. 1676), Nottingham stated:

[T] he bill charges several miscarriages and surprises upon the Lady Harvey

and several other defendants and demands several accounts. The defendant demurs because he is not concerned in many of the charges of the bill. ... Yet ordered to answer, because all the matters are so complicated and intermixt that they cannot conveniently be severed.

Note the use of a convenience test and the application of a joinder principle that can fairly be described as "common question of law or fact." Cf. FED. R. Crv. P. 20. See also Lukin v. Midleton, 73 Seld. Soc'y 340 (No. 476)- (Ch. 1676) (suit by a shareholder of a company to obtain shares as against several persons, each of whom claimed a portion of the shares).

14. Scaife v. Butler, 73 Seld. Soc'y 166 (No. 238) (Ch. 1675).

15. Greenville v. Deincourt, 73 Seld. Soc'y 304 (No. 439) (Ch. 1675) ; Anonymous, 2 Freem. 127 (No. 150), 22 Eng. Rep. 1104 (Ch. 1667) ; cf. Hole v. Harrison, Rep. t. Finch 15, 23 Eng. Rep. 9 (Ch. 1673) (in suit for contribution by surety against cosurety, all co-sureties should be joined).

16. Labrune v. Casteel, 73 Seld. Soc'y 293 (No. 424) (Ch. 1676) ; cf. Cooke v. Cooke, 2 Vern. 36, 23 Eng. Rep. 634 (Ch. 1687) (in bill by third-party beneficiary of a contract, the promisee should be joined) ; Izraell v. Narbourne, 1 Vern. 87, 23 Eng. Rep. 329 (Rolls 1682) (in bill to prevent enforcement at law of a bond executed by instant plaintiff and fraudulently assigned by sheriff, the assignee of the bond, in whose name the law action was brought, should be joined with the assignor).

17. King v. Rothwell, 73 Seld. Soc'y 108 (No. 161) (Ch. 1674).

18. Lukin v. Midleton, 73 Seld. Soc'y 340 (No. 476) (Ch. 1676).

19. Ford v. Lear, 73 Seld. Soc'y 217 (No. 311) (Ch. 1675); cf. Anonymous, 2 Freem. 52 (No. 57), 22 Eng. Rep. 1053 (Ch. 1679) (in bill to redeem a mortgage against mortgagee's heir, mortgagee's personal representative should be joined).

20. Ireton v. Lewes, Rep. t. Finch 96, 23 Eng. Rep. 52 (Ch. 1673).

21. Dunstall v. Rabett, Rep. t. Finch 243, 23 Eng. Rep. 133 (Ch. 1675) ; Atwood v. Hawkins, Rep. t. Finch 113, 23 Eng. Rep. 62 (Ch. 1673); cf. Moor v. Blagrave, 1 Ch. Cas. 277, 22 Eng. Rep. 799 (Ch. 1676) (in bill by legatee of a term to recover its possession, executor of estate from which plaintiff claims should be joined).

22. Lukin v. Midleton, 73 Seld. Soc'y 340 (No. 476) (Ch. 1676) ; Scaife v. Butler, 73 Seld. Soc'y 166 (No. 238) (Ch. 1675). 
the issues and relevant evidence, ${ }^{23}$ efficient use of judicial effort, ${ }^{24}$ and avoidance of inconsistent adjudication between different parties to the transaction.

The consideration last mentioned, avoidance of inconsistent results, was discussed in Woodcock $v$. Mayne, ${ }^{25}$ a case significant not only because of its sound reasoning but also because a century later this reasoning was ignored and the decision. swallowed up in the dogma of indispensability. ${ }^{20} \mathrm{~A}$ junior encumbrancer brought a bill to require a prior mortgagee to redeem so that the junior encumbrancer could enforce his claim; ${ }^{27}$ the defendant objected, contending that the heir of the mortgagor should be made a party. In sustaining the objection, Nottingham reasoned:

[T] he heir of the mortgagor to whom the equity of redemption is descended is not nade party, so that either the account to be now taken of what is due upon the mortgage will conclude the heir, or it will not. If it must conclude hin, then 'tis fit the heir should be called in and made privy to it. If it will not conclude him, then the defendant will be in danger to account twice unless the heir be party. So either for the heir's sake or for the defendant's sake there is a necessity of amending this bill and making the heir a party. ${ }^{28}$

It should be noted that while the opinion did not clearly indicate whether the absent heir would be bound by the result of the accounting taken in his absence, Nottingham felt quite strongly that the heir should not be so bound. This inclination in time ripened into settled law ${ }^{20}$ and now, of course, reposes in the due process clause. ${ }^{30}$ Nottingham's primary concern, then, was not that the heir would be bound. ${ }^{31}$ Rather, he pointed out that the difficulty stemmed from the fact that the absent heir would not be bound by the

23. Labrune v. Casteel, 73 Seld. Soc'y 293 (No. 424) (Ch. 1676); Ford v. Lear, 73 Seld. Soc'y 217 (No. 311) (Ch. 1675).

24. Cf. King v. Rothwell, 73 Seld. Soc'y 108 (No. 161) (Ch. 1674).

25. 73 Seld. Soc'y 314 (No. 451) (Ch. 1676). See also Thompson v. Baskerville, 3 Ch. Rep. 215, 21 Eng. Rep. 770 (Ch. 1688) (mortgagor should be joined in second mortgagee's suit to set aside first mortgage).

26. See text accompanying note 114 infra.

27. The junior encumbrancer had an "extent upon a judgment," a writ directing the sale of a judgment debtor's property.

28. 73 Seld. Soc'y at 314 .

29. On several occasions, Nottingham clearly indicated that a person not a party to an action is not bound by the result. Thus, a senior mortgagee not joined in a foreclosure suit by a junior mortgagee against the mortgagor was not barred from later foreclosing hiniself, Carpenter v. Stallard, 73 Seld. Soc'y 109 (No. 162) (Ch. 1674); Shermar v. Cox, 21 Eng. Rep. 736 (Ch. 1674), and a purchaser pendente lite of property could not be ordered to convey the property to defendant for reconveyance to plaintiff pursuant to the decree when the purchaser was not a party, Anonymous, 73 Seld. Soc'y 157 (No. 222) (Ch. 1675). In King v. Rothwell, 73 Seld. Soc'y 108 (No. 161) (Ch. 1674), involving what later became known as a class action, Nottingham seems to have had serious doubts about the binding effect of a decree on absentees. As is recognized today, the class action is one of the principal exceptions to the rule that a person not joined is not bound. Interestingly enough, however, the class action still raises serious doubts. See Hansberry v. Lee, 311 U..S. 32 (1940).

30. See, e.g., Hansen v. Denckla, 357 U.S. 235 (1958); Pennoyer v. Neff, 95 U.S. 714 (1877).

31. The supposition that the absentee will be bound is, of course, the premise of the jurisdictional theory of indispensability. See note 6 stipra. 
accounting and hence might subject the defendant to a second and perhaps inconsistent accounting. ${ }^{32}$ This analysis not only differs from but is completely antithetical to the later developed notion of indispensability and the premises supposedly underlying it.

Nottingham's practical approach to the problem of necessary parties is revealed with even greater clarity by his decisions excusing joinder of parties who would normally have been considered necessary or, latterly, indispensable. In these decisions, we can discern what would today be called "balancing of conveniences." 33 Plaintiff was required to do all he could to bring in the necessary parties, ${ }^{34}$ but their joinder was excused when inconvenient for one reason or another. Thus, in a bill to enforce a charitable charge against certain lands, the defendants' demand that tenants of other lands also subject to the charge be joined was overruled, the defendants being left to their remedy of contribution by separate proceedings. ${ }^{35}$ Implicit is the idea, later to become articulate, that the favored action for the benefit of a charity should not be thwarted by the procedural necessities of the defendant. A later case ${ }^{36}$ involved a bill by an obligee to recover interest due on a bond executed by a number of obligors. The defendants apparently had made an arrangement by which, in rotation, they would fail to appear at hearing, ${ }^{37}$ so that despite several postponements the plaintiff was unable to get all necessary parties before the court. Nottingham said crisply: "Here was an affected delay. So I decreed for the plaintiff and turned the labour on the defendant to play his aftergame for contribution against the rest." 38

In dealing with the problem of necessary parties who were not before

32. Furthermore, when the absentee is bound by the decree because his rights are derivative from one of the parties, the absentee need not be joined. See Tattswell $v$. Cowper, 73 Seld. Soc'y 219 (No. 315) (Ch. 1675).

33. See N.Y. TEMP. CoMm'n on the Courts, First Preliminary Report of THe Advisory ComantTee on Practice AND Procedure, Rule 23.1, at 28-29 (1957).

34. Thus, in Thompson v. Baskerville, 3 Ch. Rep. 215, 21 Eng. Rep. 770 (Ch. 1688), involving a second mortgagee's bill to set aside the first mortgage as fraudulent, the plaintiff alleged that the mortgagor was outside the jurisdiction and hence not amenable to process. The court asserted that plaintiff "ought to have the Mortgagor's Answer, or run out all the Process of Contempt to a Sequestration, before he can hear his Cause against the Defendant. For no Contempt can be without Service of the Subpoena." Id. at 215, 21 Eng. Rep. at 770.

It had been settled that when plaintiff's bill sought discovery of necessary parties, he need not initially join the unknown party. Bowyer v. Covert, 1 Vern. 95, 23 Eng. Rep. 337 (Ch. 1682) (bill to discover defendant's co-executor).

35. Coleman v. Coleman, 73 Seld. Soc'y 4 (No. 8) (Ch. 1673). The terms of the will creating the charitable charge seem to have created what was and still is known as a "joint" obligation, as distinct from a "joint and several" obligation. This did not concern Nottingham; he recognized that the interest in enforcing a charity's claim outweighed the defendant's interest in avoiding a multiplicity of suits and/or being forced to pay a disproportionate amount of the charge. For later instances in which a "joint" obligation was enforced against only one of the joint obligors, see notes 42, 65 infra. The notion that all obligors of a joint obligation are indispensable parties in actions to enforce such an obligation thus seems clearly a later invention.

36. Cranborn v. Crisp, 73 Seld. Soc'y 58 (No. 104) (Ch. 1674).

37. Default decrees were not available under the practice of the time.

38. 73 Seld. Soc'y at 59 . 
the court, reliance at times was placed on the device known today as the class action $;^{39}$ in other instances, a notion akin to the modern idea of privity seemed to be applied, so that joinder of the absentee was unnecessary because he would be bound by the result reached as to the parties already present. 40 At other times, however, the court simply proceeded to do what it could.

The most interesting of these early cases excusing joinder of necessary parties is Walley $v$. Walley, ${ }^{41}$ the first case to face squarely the question of how to proceed when a necessary party is outside the jurisdiction. Plaintiff's grandfather had established a trust for plaintiff's benefit with his father as trustee. The father breached his fiduciary duty by selling entrusted bonds, and the beneficiary brought suit for an accounting against the buyers, who had notice of the breach. In answer to the defendant's claim that the father should be joined, plaintiff established that his father was with the army in India and hence not amenable to process. Nottingham, applying a principle that had been suggested, and perhaps authoritatively laid down, at an earlier date, ${ }^{42}$ held quite simply that plaintiff might proceed. ${ }^{43}$

The procedural principle disclosed by these cases continued to be applied after Nottingham's tenure as Chancellor. It can be summarized by saying that joinder of all interested parties is required ${ }^{44}$ except where impossible,

39. Brown v. Vermuden, 1 Ch. Cas. 272, 22 Eng. Rep. 796 (Ch. 1676) ; cf. Attorney General v. Ryder, 2 Ch. Cas. 178, 22 Eng. Rep. 901 (Ch. 1686).

40. See Anonymous, 1 Vern. 261, 23 Eng. Rep. 456 (Ch. 1684) (in bill against executors, plaintiff need not join beneficiaries of testamentary trust or residuary legatees); Needler v. Deeble, 1 Ch. Cas. 299, 22 Eng. Rep. 810 (Ch. 1678) (in absence of collusion, second mortgagee held bound by accounting between mortgagor and first mortgagee).

41. 1 Vern. 484, 23 Eng. Rep. 609 (Ch. 1687).

42. In Castleton v. Fitzwilliams, Cary 100, 21 Eng. Rep. 53 (Ch. 1579), a bill was brought against a feme covert for loss of goods carried on a ship of which defendant's husband was the master. It was alleged that her husband was not joincd because he was absent from the jurisdiction under a fourteen year sentence to the Spanish galleys. The reporter says that on defendant's demurrer for want of parties, "it is ordered, a subpoena be awarded against her to make a better answer." Id. at 101, 21 Eng. Rep. at 54.

In Barker v. Wyld, 1 Vern. 140, 23 Eng. Rep. 373 (Rolls 1682), a bill of account for a joint demand was brought against two of three factors who were parties to the obligation. It was said that the plaintiff might so proceed "and that there are divers precedents of it." Ibid. The reporter added this suggestive note: "Sed $Q$. If it be not only, where other factors are beyond the sea." Id. at 140, 23 Eng. Rep. at 373.

Later courts would regard these situations as presenting indispensable party problems-involving, respectively, the indissoluble bonds of marriage and joint obligationand often would refuse to proceed. The seventeenth century court was not so timorous.

43. A similar result was reached in 1698. Cowslad v. Cely, Prec. Ch. 83, 24 Eng. Rep. 40 (Ch. 1698) (suit by legatee against one of two joint executors for an accounting of the executor's own receipts; other executor beyond the sea).

44. Knight v. Knight, 3 P. Wms. 331, 24 Eng. Rep. 1088 (Ch. 1734). See also Anonymous, 2 Eq. Ca. Abr. 167 (No. 15), 22 Eng. Rep. 143 (Ch. 1720); I Iirk v. Clark, Prec. Ch. 275, 24 Eng. Rep. 133 (Ch. 1708). In the case last mentioned, it is explicitly recognized that a party not joined is not bound. Accord, Godfrey v. Chadwell, 2 Vern. 601, 23 Eng. Rep. 993 (Ch. 1707) (second mortgagee not joined in foreclosure suit not bound by decree in favor of first mortgagee against mortgagor).

In a note in Sangosa v. East India Co., 2 Eq. Ca. Abr. 170 (No. 28), 22 Eng. Rep. 145 (Ch., year unknown-probably 1720), it is said that "all Persons necessary to the 
inconvenient, or unduly burdensome. If the absent party was outside the jurisdiction ${ }^{45}$ or outlawed $;^{46}$ if absentee defendants were so numerous that it would be difficult to bring them all before the court; 47 if the defendant at the time he incurred the obligation sued on knew the absentee would probably be out of the jurisdiction, ${ }^{48}$ or if he had obstructed efforts to obtain service on the absente $e^{49}$-joinder was not required. In some cases the principle of representation was used, ${ }^{50}$ in others it was suggested that the risk of subsequent inconsistent adjudication was small, ${ }^{51}$ and sometimes it

Relief must be made Parties." This is one of the earliest uses of the term "necessary" parties. Furthermore, the language of the note embodies the later fallacy of the indispensable party rule-that there are parties who must be joined before any relief ("the relief") can be granted. Properly interpreted, the report doubtless should have read "necessary to complete relief." For a discussion of this confusion, see text accompanying notes 143-144 infra.

45. In Quintine v. Yard, 1 Eq. Ca. Abr. 74 (No. 19), 21 Eng. Rep. 886 (Ch. 1702), a testator had charged all his lands with an annuity to $B$, devising his lands, subject to the charge, as follows: his lands in England to his daughters, the instant defendants, and his lands in Barbadoes to two other daughters who lived there and who were not made parties to the action. To defendant's objection that the Barbadoes daughters should be joined, it was said: "Admit it to be so, in case it may be easily done, yet it is impractical in this case, and therefore ought not to be required . . ." Id. at 74, 21 Eng. Rep. at 886. See D'Aranda v. Whittingham, Mos. 84, 25 Eng. Rep. 285 (Ch. 1728); Monill v. Lawson, 2 Eq. Ca. Abr. 167 (No. 13), 22 Eng. Rep. 143 (Ch. 1719) (no defect of parties when one of several trustees who not joined was alleged to be beyond the sea); cf. Rogers v. Linton, Bunb. 200, 145 Eng. Rep. 647 (Ex. 1725) (Gilbert, L. B.), in which a decedent had three wives, by the first of whom he had two children, by the second one child and by the third four children. $\mathrm{He}$ devised his property "one third to his wife, and one third to all his children, and the other third to the children by the last wife." The children of the third wife sought to have the third given to all the children awarded to them, on the ground that the children by the first two wives had been provided for during testator's lifetime. The child of the second wife was not joined and was alleged to be beyond the sea. Held, plaintiff may proceed.

See also Newsome v. Bowyer, 3 P. Wms. 37, 24 Eng. Rep. 959 (Ch. 1729) (semble) (feme covert whose husband is beyond the sea may sue without joining him); Bell v. Hyde, Prec. Ch. 328, 24 Eng. Rep. 155 (Ch. 1711) (wife whose husband is beyond the sea may be sued without joining him); Dubois v. Hole, 2 Vern. 613, 23 Eng. Rep. 1002 (Ch. 1708) (same).

46. Heath v. Percival, 1 P. Wms. 682, 24 Eng. Rep. 570 (Ch. 1720).

47. Attorney General v. Wyburgh, 1 P. Wms. 559, 24 Eng. Rep. 534 (Ch. 1719) (charitable charge against several lands; owners of other charged lands need not be joined): See also Anonymous, 2 Eq. Ca. Abr. 166 (No. 7), 22 Eng. Rep. 141 (Ch. 1709), involving a creditor's bill against sixteen of 250 subscribers to a defunct bank to collect the defendants' pro rata liability for the bank's obligations. The court observed that "if there should happen to be any Disproportion in the Accontsts, the Party grieved may have his Remedy by Bill." Id. at 166, 22 Eng. Rep. at 141.

It should be borne in mind that one of the most serious obstacles to prosecution of a multiparty bill was that the suit abated upon death of a party and it was necessary to start over again practically from the beginning. This problem was repcatedly adverted to in the reports. holding).

48. Colton v. Wilson, 3 P. Wms. 190, 24 Eng. Rep. 1025 (Ch. 1733) (alternative

49. D'Aranda v. Whittingham, Mos. 84, 25 Eng. Rep. 285 (Ch. 1728).

50. Jones v. Goodchild, 3 P. Wms. 33, 24 Eng. Rep. 958 (Ch. 1729) (executors may sue to recover property of estate without joining beneficiaries of estate) ; Chancey v. May, Prec. Ch. 592, 24 Eng. Rep. 265 (Ch. 1722) (bill by treasurer and manager of a brass works on behalf of themselves and all other proprietors of the works against former officers of the works to recover misappropriated funds).

51. In Colton v. Wilson, 3 P. Wms. 190, 24 Eng. Rep. 1025 (Ch. 1733), a testator had devised lands to trustees to sell and pay testator's debts. The trustees, plaintiffs in the action, contracted with defendant for sale of some of the land. To a bill for specific performance, defendant objected that the testator's heir should be joined so 
was pointed out that plaintiff was limiting his prayer for relief to those defendants before the court. ${ }^{52}$ On the other hand, when the defendant was in obvious peril of being subjected to double liability, there was firm insistence that the other claimants be joined. ${ }^{53}$ In none of these cases, however, was there any mention of indispensable parties.

\section{Eighteenth Century Developments}

\section{A. The Early Eighteenth Century Treatises}

By the first quarter of the eighteenth century there had developed enough consciousness of precedent-and enough precedent of which to be consciousto stimulate the writings of books on Chancery practice. ${ }^{54}$ These treatises varied in approach, some being abridgments with a minimum of independent editorial content and others showing some of the narrative style of later treatises. They also varied in quality, ranging from efforts to do a fairly thorough job to little more than hornbooks for students. The attempts at generalization in these works are significant for several reasons: they indicate the thinking of the time; they served as source material for later lawyers; and they reveal the difficulty inherent in formulating rules to deal with the problem of parties to suits.

The first of the practice books was Browne's Praxis Almae Curiae Cancellariae.55 Browne's book is badly organized by modern standards and does not throw much light on parties problems. It has a very brief introductory textual treatment of Chancery practice, a collection of Chancery writs, Orders in Chancery and, the bulk of the work, forms of various pleadings.

that marketable title could be conveyed. Plaintiff answered that the heir was abroad. The court overruled the objection for want of parties, stating that the will, like a deed, can be "established in equity" without joinder of the heir. It is not clear whether the court was suggesting that the heir would be bound or whether, because the will was subject to no apparent defect, there was only a remote possibility that the heir could later upset defendant's title. If the former, the case may be viewed as one of the early strands of precedent from which was later fashioned the idea of in rem jurisdiction. See also Harris v. Ingledew, 3 P. Wms. 91, 24 Eng. Rep. 981 (Rolls 1730) (creditors' bill to rcach lands held by trustees under testamentary direction that trustees pay debts; heir at law not joined; bill disclosed that lands had been quietly enjoyed under the will for ten years).

52. Selyard v. Executors of Harris, 1 Eq. Ca. Abr. 74 (No. 20), 21 Eng. Rep. 886 (Ch. 1711) (bill for accounting of property received by one of three trustees: "Plaintiff insisting only to have an Account of what eame to the Proper Hands of Harris, and of his Receipts and Disbursements only, and not of any Joint-Receipts or Transactions by him, with the other Trustees"); Draper v. Jennings, 2 Vern. 518, 23 Eng. Rep. 931 (Ch. 1705) (bill by first mortgagee to foreclose against mortgagor and second mortgagee; other junior encumbrancers not joined; plaintiff can foreclose against "such defendants as he had brought before the court").

53. Hooper v. Lethbridge, Bunb. 291, 145 Eng. Rep. 678 (Ex. 1730).

54. See generally 12 Holdsworth 179-82 (1938).

55. The first edition of Browne was $1694 / 95$. There were several subsequent editions, see 12 HoLDSwORTH 179-80 (1938), of which I have examined the second (1704) and fourth (1725). These two editions appear to be the same insofar as they deal with matters relevant to the present inquiry. 
While undoubtedly of value to the contemporary practitioner, it has little to offer today. ${ }^{50}$

The second important practice treatise is Bohun's Cursus Cancellariae. ${ }^{57}$ He states the rules governing joinder of parties as follows:

In all suits in Equity great Care is to be taken, that there be proper Parties named in the Bill, for and against whom the Court may respectively make a Decree: For if upon the Face of the Bill it appears that any, whose Right or Interest is concern'd, or who ought to have been, are not made Parties therein, the Defendant may demur to such Bill; or if he does not, yet the Court, upon hearing, will not, for Want of them, proceed to a Decree; or if it does, the Decree may be revers'd; or if it be not revers'd, yet none, but such were made Parties to the Suit, and those claiming under them, can be bound by the Decree. ${ }^{58}$

Several observations can be made about this passage. In the first place, Bohun is very vague about who are necessary parties. Such vagueness is characteristic of the procedural writing of that period and many ycars afterward, and is harmless unless it is treated, as in later ycars it seems to have been, as purporting to be definitive. More interesting is the fact that Bohun does not mention the exceptions to the necessary party rule..$^{59}$ It is possible that this omission by Bohun and later writers, coupled with reiteration of the general rule that all who are interested must be joined, played a part in the later belief that necessary parties meant, in some situations at least, indispensable parties. The point to be observed is that in light of the then decided cases, Bohun must be taken as stating a general principle of procedural policy rather than setting forth with technical accuracy the actual content of the necessary parties rule.

A third writer, Giles Jacob, did not differ much from Bohun. ${ }^{60}$ Indeed, his language so closely parallels Bohun's as to suggest that he cribbed. ${ }^{61}$

56. In Browne's text, he observes that "No Decree shall be binding to any, but those who are served with Process Ad Audiendum Judicium, or that did appear gratis," a recognition of the rule that a person not joined is not bound. 1 BRowne, Praxis Alatae Curiae Cancellariae 26 (1st ed. 1694/95). In his collection of Orders in Chancery, in the second edition, he sets forth an order recognizing that omission of a party does not invalidate a decree: "Where one that is a Trustee is omitted to be named a Defendant in a Bill, yet that shall be no cause to avoid a Decree." 1 id. at 523 (2d ed. 1704). His pleading forms include at least two examples of demurrer for want of parties. 2 id. at 416, 421, 426, 429.

57. Bohun, Cursus Canceliartae (2d ed. 1723). There appears to be no extant copy of the first edition. See 12 Holdsworth 180 n.3 (1938).

58. BOHUN, op. cit. supra note 57, at 459-60.

59. See text accompanying notes $41-52$ supra.

60. Jacob, The CoMfrleat Chancery-Practiser 139-40 (1730):

In all Suits in Equity by English Bill great Care is to be taken that there be proper Parties named in the Bill; and if those whose Right is concerned, are not made Parties, the Defendant may demur to such Bill; of if he doth not, the Court will not Proceed to a Decree; of if a Decree be made thereon, it may be reversed.

61. Jacob's book was probably a handbook for students. Cf. Cowley, BIBLIOGRAPHY of Abridgarents lvii (Seld. Soc'y 1932). 
Again, we have what must be regarded as loose generalization rather than precise restatement of procedural law.

\section{B. The Rules in the Middle of the Eighteenth Century}

1. Lord Hardwicke. After Lord Nottingham, the next great figure to sit as Lord Chancellor was Phillip Yorke, Lord Hardwicke, who held the office from 1737 to $1756 .{ }^{62}$ During his tenure, the parties rules developed by Nottingham were more fully articulated. The pattern of decision, however, remained the same.

The general rule, requiring joinder of all interested parties, was ordinarily applied. ${ }^{63}$ However, in addition to the cases excusing joinder of an absentee who was out of the country, an exception was recognized when the absent party was not subject to process because he was a party to a proceeding in another court. In such a case, he was treated as being beyond the jurisdiction of the court and his joinder, therefore, was excused. ${ }^{64}$

Darwent $v$. Walton $^{65}$ presented, once again, the problem of an absentee beyond the sea. In this ease, involving a bill to recover on a joint demand against one of two partners, it was alleged that the absent partner was out of the jurisdiction. Two questions were thereby presented: first, whether plaintiff could proceed at all without joining the other obligor and, second, if he could so proceed, whether the defendant obligor was liable for the entire debt or only half of it. In a carefully reasoned opinion, Hardwicke made it quite clear that the plaintiff could sue one joint obligor and recover the

62. See generally 12 HoLdswoRTh $237-97$ (1938).

63. See Pyncent v. Pyncent, 3 Atk. 571, 26 Eng. Rep. 1129 (Ch. 1747) (in remainderman's bill to compel life tenant to deliver title deeds, annuitants with charge on estate should be joined); Howes v. Wadham, Ridg. T. H. 199, 27 Eng. Rep. 803 (Ch. 1744) (in mortgagee's bill to compel purchaser from mortgagor to complete purchase and redeem or be foreclosed, heir of mortgagor should be joined) ; Poore v. Clark, 2 Atk. 515, 26 Eng. Rep. 710 (Ch. 1742) (in bill to order a building torn down, owner in fee of premises on which building stood, as well as lessee of premises, should be joined); Ashurst v. Eyre, 2 Atk. 51, 26 Eng. Rep. 428, subsequent procecdings, 3 Atk. 341, 26 Eng. Rep. 997 (Ch. 1740) (in bill for discovery of assets in hands of decedent, decedent's administrator should be joined); Glass v. Oxenham, 2 Atk. 121, 26 Eng. Rep. 476 (Ch. 1740) (in bill to recover a charge on an estate, unpaid for many years, executor holding office during the period, as well as present successor executor, should be joined); Benson v. Baldwyn, 1 Atk. 598, 26 Eng. Rep. 377 (Ch. 1739) (in bill to establish the rents due from lands, the terre-tenants must be joined); Herring v. Yoe, 1 Atk. 290, 26 Eng. Rep. 186 (Ch. 1737) (in husband's suit for construction of a marriage settlement, wife should be joined along with settlement trustees).

64. See Plunket v. Penson, 2 Atk. 51, 26 Eng. Rep. 428 (Rolls 1740) (administrator contesting in ecclesiastical court).

This situation seems the closest English analogy to the problem later to arise in federal diversity cases when the absentee, though within the territorial jurisdiction of the federal court, could not be joined without destroying the required complete diversity. See, e.g. Joy v. Wirtz, 13 Fed. Cas. 1172 (No. 7553), subsequent procecdings, 13 Fcd. Cas. 1172 (No. 7554) (C.C.D. Pa. 1806), discussed in text accompanying notes 128-

139 infra. See generally Reed, Compulsory Joinder of Partics in Civil Actions, 55 MICH. L. REv. 483, 517-37 (1957).

65. 2 Atk. 510, 26 Eng. Rep. 707 (Ch. 1742). See also Travers v. Buckly, 1 Ves. Sen. 383, 27 Eng. Rep. 1095 (Ch. 1750). 
whole obligation from him. ${ }^{66}$ This case indicates as precisely as any that the necessary party rule, in the middle of the eighteenth century, had none of the inexorability of the later indispensable party rule.

The flexibility of the practice in Hardwicke's time is demonstrated by a number of cases in which we find increasingly explicit references to the considerations of procedural policy underlying the necessary party rule and its exceptions. Thus, when the reason for joining an interested party was to obtain contribution from him in favor of one of the parties already joined, the absentee's joinder was not required if he was insolvent. ${ }^{67}$ Furthermore, Hardwicke at times adopted the technique, which might commend itself to modern courts, of postponing decision of the parties question until the merits had been investigated, with the end in view that the parties problem might thereupon become moot. ${ }^{68}$ In two cases at this time the court explicitly engaged in a balancing of competing interests, ${ }^{69}$ and, after some uncertainty,

66. Hardwicke noted the adoption of An Act for Making Process in Courts of Equity, 1732,5 Geo. 2 , c. $25, \S 1$, which provided that if a defendant who had been summoned refused to appear the court could enter a decree pro confesso against him. He then said:

Before the act, you might carry it on through the whole line of process against a defendant, who did not appear to the sequestration, and no further; but you might, notwithstanding, set down the cause against the other defendant, and have a decree for the whole.

If you could do this before the act of parliament, where a person was in the kingdom, but obstinately refused to appear, much more ought the court to make a decree against one partner, where the other is out of the kingdom, that an account should be taken, and the whole which appears to be due the plaintiff should be paid by the defendant, the partner who is brought to a hearing. .6

2 Atk. at 511, 26 Eng. Rep. at 707. See also Williams, Jornt Obligations 51-53 (1949).

67. Madox v. Jackson, 3 Atk. 406, 26 Eng. Rep. 1034 (Ch. 1746). But cf. Ashurst v. Eyre, 2 Atk. 51, 26 Eng. Rep. 428, subsequent proceedings, 3 Atk. 341, 26 Eng. Rep. 997 (Ch. 1740).

68. See Williams v. Williams, 9 Mod. 299, 88 Eng. Rep. 465 (Ch. 1742), involving a bill by beneficiaries of a testamentary trust for payment of their legacies. Defendant, heir of the trustee, objected that the trustee's personal property was primarily liable for the legacies and hence the trustee's executor should be made a party. Hardwicke held that under the terms of the will the entrusted real property was primarily liable and thus the executor need not be joined. Cf. Madox v. Jackson, supra note 67 (bond admittedly unpaid; no joinder required of those normally necessary for an accounting of the amount unpaid). See also Peacock v. Monk, 1 Ves. Sen. 127, 27 Eng. Rep. 934 (Ch. 1748).

69. In Yates v. Hambly, 2 Atk. 237, 26 Eng. Rep. 547 (Ch. 1741), a bill by a mortgagor to redeem, the defendant mortgagee pleaded that he had conveyed his interest with several limitations over and that the holders of these interests should be joined. The court indicated that if plaintiff's right to redeem was clear and the defendant had complicated plaintiff's remedy by an involved conveyance, joinder would not be required; but otherwise when plaintiff's right depended on 'equitable circumstances, and $\ldots$ is not ... the common case of redemptions .... Id. at 238,26 Eng. Rep. at 547. See Bradwin v. Harpur, Amb. 374, 27 Eng. Rep. 249 (Rolls 1759), a bill by a legatee for reformation of a will on the ground of mistake in which it was held that the next of kin of the testator, who would take should the gift fail, need not be joined. "[T] next of kin appearing to be numerous, and living in distant places, and the matter in dispute being very small, and the plaintiff a pauper, his Honor decreed the money to be paid." Id. at 375, 27 Eng. Rep. at 249. See also Ex parte Angel, 2 Atk. 162, 26 Eng. Rep. 502 (Ch. 1741) (in bill for accounting against managers of charitable subscription, joinder of executors of deceased managers excused, each being considered answerable for the others). 
determined that the proper disposition of a bill defective in parties is to have it stand over, with amendment if necessary, and not to dismiss it. ${ }^{70}$ Finally, the class action was used to obviate joinder, ${ }^{71}$ and, again with some uncertainty, the rule that a party not joined is not bound was applied. ${ }^{72}$

One of Lord Hardwicke's cases, Attorney General v. Baliol College,73 is particularly noteworthy because it appears to have played an important part in the later emergence of the indispensable party concept. One Snell had established a trust, the proceeds of which were to be used to provide five scholarships at Oxford for Scottish students from the University of Glasgow who promised upon finishing Oxford to enter the Anglican ministry in Scotland. Any surplus from the trust fund was to be used to provide additional scholarships of the same nature. The named trustees were designated officials of the colleges at Oxford. The Snell trust was created during the period when the Anglican Church was the established church in Scotland. When, at the end of the seventeenth century, the Anglican Church was disestablished and the Presbyterian Church reestablished, the Snell trust's immediate purpose failed. Thereupon, Snell's heirs sued the trustees to reclaim the property. Relief was refused, the court applying the cy-pres doctrine and decreeing that the funds should be used: (1) to provide five scholarships for Scottish students from Glasgow University, free of the requirement that the recipients enter the ministry, and (2) the surplus to be used for maintenance of the library at Baliol College, Oxford. The University of Glasgow was not a party to this litigation.

Subsequently, Glasgow demanded that the entire trust fund be used for scholarships for its students and not siphoned off for the Baliol library. When

70. Jones v. Jones, 3 Atk. 110, 26 Eng. Rep. 867 (Ch. 1744); Anonymous, 1 Atk. 15, 26 Eng. Rep. 406 (Ch. 1737) (A bill in chancery, said Lord Hardwicke, "is never dismissed for want of parties, but stands over, upon paying the Costs of the day."); See Ashurst v. Eyre, 2 Atk. 51, 26 Eng. Rep. 428, subsequent proceedings, 3 Atk. 341, 26 Eng. Rep. 997 (Ch. 1740).

71. Mayor of York v. Pilkington, 1 Atk. 282, 26 Eng. Rep. 180 (Ch. 1737). In Leigh v. Thomas, 2 Ves. Sen. 312, 28 Eng. Rep. 201 (Rolls 1751), there is what appears to be an interesting insistence on the use of the class device. The stit was a bill by two members of a ship's crew who had by deed and assignment been appointed, by sixty-four of the eighty members of the crew, agents for the collection of the sixty-four members' share of the proceeds of a voyage. Defendant's demurrer for failure to makc all members of the crew parties was allowed, the Master of the Rolls indicating that plaintiffs should allege that the suit was brought on behalf of the whole crew.

72. Two of the cases indicate quite clearly that a person not joined is not bound. Indeed, this was the reason offered why a necessary party should be joined. Sec Howes v. Wadham, Ridg. T.H. 199, 27 Eng. Rep. 803 (Ch. 1744); Poore v. Clark, 2 Atk. 515, 26 Eng. Rep. 710 (Ch. 1742). On the other hand, a dictum, apparently by the Master of the Rolls, contains the precisely opposite thought. In Pawlet v. Bishop of Lincoln, 2 Atk. 296, 26 Eng. Rep. 581 (Ch. 1742), it was said that "you must have all persons before the court who have any pretence to a right; for, by a decree of this court, they will be bound." Id. at 296, 26 Eng. Rep. at 581. In other words, the absentee should be joined, not in order to bind him, but becanse he will be bound. This is the very kind of wooly thinking that is later found in the indispensable party cases. It seems not to have been the law then and certainly was not the law in later years. 73. 9 Mod. 407, 88 Eng. Rep. 538 (Ch. 1744). 
this demand was refused, Glasgow brought the instant proceeding, on relation of the Attorney General, to compel Baliol so to apply the trust fund. Baliol set up the prior decree, ${ }^{74}$ to which Glasgow responded that the decree was void because it had not been joined. ${ }^{75}$ Hardwicke's response, which covered a number of points, was this:

As to their being not parties, that will not avail them much; for [the prior suit] was not brought in a collusive secret manner. ... Glasgow indeed was no party, nor indeed were the plaintiffs [in that suit] obliged to make that University party, for it is a corporation, and out of the kingdom and reach of the process of this court, which is always an excuse for not making them parties: therefore that is no objection to make this a void decree as to them. ${ }^{76}$

He then determined that Glasgow could not have the decree set aside. ${ }^{77}$

Analyzing this decision in terms of eighteenth century procedural and substantive concepts is perilous, but a few observations can be made. There seems to be the suggestion that the trustees, absent "collusive secret" conduct, adequately represented the interests of the beneficiaries of the trusta notion that, with many refinements, later became established law. ${ }^{78}$ The procedural significance of this point is that a person who is adequately represented by someone who is a party need not himself be a party; the absentee will be protected (and will be bound) by the party who represents him. It seems fair to say that Hardwicke was suggesting something akin to this; namely, that Glasgow was bound because it was represented.79 But beyond this we cannot go. ${ }^{80}$ Indeed, the most significant point about the decision is the great difficulty of ascertaining what was the ratio decidendi. Later writers attempted to explain the case as holding that a "passive party"Glasgow-need not be joined. The resulting dichotomy of "active" and "passive" parties created much of the difficulty surrounding the indispensable party rule..$^{81}$

74. Baliol asserted other defenses, laches and estoppel, but these are irrelevant here.

75. It seems fairly clear that Glasgow was contending not merely that the decree did not bind it, but also that the decree was void because Glasgow was not joined. This is in substance the argument that underlies the indispensable party doctrine-a decree made in the absence of a vitally interested party is jurisdictionally defective. It should be observed that the argument was flatly rejected by Hardwicke.

76. Id. at 409, 88 Eng. Rep. at 539.

77. Glasgow had long delayed in making its objection to the original decree, allowing about thirty years to pass before bringing the instant proceeding. This could well be deemed laches or estoppel, though Hardwicke did not expressly refer to such concepts. Hence, the language quoted in the text may possibly be considered dictum.

78. See RESTATEMENT, JudgMENTS \& 85 (1942).

79. The facts disclose a situation that in later years might have been characterized as an in rem proceeding, an action in which a court determines the interests of all concerned in specific property. See id. $\$ 32$. It would be anachronistic to suggest such a basis for an eighteenth century decision.

80. In passing, it is worth noting Hardwicke's reference to the fact that Glasgow was a corporation. This seems to be a reference to the idea, prevalent in the nineteenth century, that a corporation cannot exist outside the territorial limits of the jurisdiction in which it was created. See generally Henderson, THE Posrtion of FOREIGN CORPORATIONS IN AMERICAN CONSTITUTIONAL LAW (1918).

81. See text accompanying notes 111 \& 142 infra. 
One final decision by Hardwicke should be noted, for it contains a reference to "formal" parties, a term later used in association with passive parties in the dichotomy mentioned above. In Jones v. Jones, ${ }^{82}$ plaintiff executed a lease, apparently as security for a debt owed defendant, to certain trustees in trust for the defendant. Plaintiff charged in his bill, to which the trustees were not made parties, that he was fraudulently induced to execute the lease. Defendant made no joinder of parties objection at the pleading stage but did so at hearing. Hardwicke said:

[I]t will be too late to make the objection when the cause comes on again, if it was put off only for want of formal parties by the court, in order that the decree might be complete.

In a decree to account, if, during the account, any party should die, and a devisee of that party, or any other formal party as trustees (which is the present case) should be wanting, a bill to bring them before the court is not, in the strict sense of the word, a supplemental bill, but rather a supplemental bill in the nature of a bill of revivor .... 83

It should be noted that Hardwicke did not say that formal parties need not be joined in the first instance; he said that the objection will be overruled if not timely taken. Hence, his language should not have been taken, as later it was, as distinguishing between those who must be joined in order to make a decree and those who need not be. On the contrary, Hardwicke recognized that formal parties were joined "in order that the decree might be made complete." In other words, he recognized that the decree could not be complete without the formal parties, but he was willing to make an incomplete decree because the objection had come so tardily. In later years, this understanding was distorted into the principle that while a decree can be entered without formal parties, it can not be entered if "nonformal" (or "active") parties are not joined. Hardwicke was willing to make an incomplete

82. 3 Atk. 110, 26 Eng. Rep. 867 (Ch. 1744), subsequent procecdings, 3 Atk. 217, 26 Eng. Rep. 927 (Ch. 1745).

The earliest suggestion found of the formal party notion is in Kirk v. Clark, Prec. Ch. 275, 24 Eng. Rep. 133 (Ch. 1708). This was a bill by trustees, named in marriage articles, against the husband and others for specific performance of the articles. Defendants' objection to failure to join the wife was sustained, but it was ordered that the pleadings and depositions thus far taken were to stand notwithstanding the joinder of the wife as a new party. Ordinarily, depositions could not be read against those not party to the suit, so that when additional parties were joined the normal practice would require that the depositions previously taken be disregarded and new ones taken. Furthermore, joinder of an additional party ordinarily required amended pleadings. The fact that the court ordered the pleadings and depositions to stand suggests that the addition of the wife as a party was regarded as a purely formal matter, not altering the posture of the controversy.

In Bell v. Hyde, Prec. Ch. 328, 24 Eng. Rep. 155 (Ch. 1711), a reference is made that in terms connotes formal party. The suit was to collect a note executed by a wife to pay her husband's debts, in which plaintiff attached the wife's separate estate. The husband was not joined, it being alleged that he was in Rotterdam. Defendant's objection to failure to join the husband was overruled, the court saying that "the husband was joined in the Suit only for Conformity." Id. at 330, 24 Eng. Rep. at 156.

83. 3 Atk. at 217,26 Eng. Rep. at 927. 
decree; later courts were unwilling to do so, and simply because they supposed they could not do so. ${ }^{84}$

2. The mid-century text writers. The text writers of the time took cognizance of the developments in procedural doctrine that occurred during Hardwicke's tenure. The most significant and respected work is Lord Chief Baron Gilbert's History and Practice of the High Court of Chancery, published in 1758.85 Gilbert summarized the parties rules as follows:

If it appears that a very necessary party is wanting, that without him no regular decree can be made; as where [giving a number of concrete examples of necessary parties] .... In these and other cases, where the decree cannot be made uniform, for as on the one hand, the court will do the plaintiff right, so on the other hand they will take care that the defendant is not doubly vexed, he shall not be left under precarious circumstances, because of the plaintiff, who might have made all proper parties at first, and whose fault it was that it was not so done ... . 86

Like the earlier writers, ${ }^{87}$ Gilbert did not mention the exceptions to the necessary party rule-absence, insolvency, etc. Moreover, while he pointed out that the real basis for compulsory joinder is to ensure that the absentees will be bound, so as not to leave a defendant in "precarious circumstances," he also relied on the artistic but unsound reason that complete joinder will permit entry of a "regular" or "uniform" decree. Holdsworth has noted that as the eighteenth century wore on, Chancery became increasingly preoccupied with the quest for "perfect justice," 88 for beauty and symmetry of form rather than utility of practical result. As we shall see, it was precisely this attitude that led to the indispensable party rule. Gilbert's language discloses this sentiment and foreshadows the rule.

Joseph Harrison, the other writer of the time, while less celebrated, seems to have been more accurate than Gilbert. ${ }^{89}$ Harrison did not attempt the breadth and majesty of Gilbert's treatise and in his workaday writing avoided the generalizations in Gilbert that bred later troubles. Harrison's discussion is somewhat disconnected, being in part an abridgment of cases and in part what today we would call text. His textual discussion is as follows :

Regularly all that are interested are to be made Parties, otherwise the Defendant may demur; or if he doth not, the Court will not

84. This interpretation is borne out by Hardwicke's reference to the bill of revivor when a party to an account died: the revivor was necessary to dispose of the case and to make it clear that the decree operated to bind the devisee of the party. Since the decree could not be proper as to form until this was done, the devisee was in this sense a formal party.

85. See 12 Holdsworth 182 (1938).

86. Gilbert, The History and Practice of the High Court of Chancery 157-

87. See text accompanying note 59 supra.

88. See 9 Holdswort $347-48$ (1926).

89. Harrison's book first appeared in 1741 and went through several editions. See $12 i d$. at 181 (1938). 
proceed to a Decree, or if a Decree be made, it may be reversed; but if it be not reversed, yet none but such as were Parties and those claiming under them can be bound by it. ${ }^{90}$

It should be observed that Harrison opened his general statement of the rule, quoted above, with the term "regularly," implying that this was the ordinary but not invariable rule. It should be noted further that Harrison recognized that a party not joined was not bound. The author then proceeded to give examples of situations in which joinder was required and situations in which joinder was excused, as when one of two co-executors or co-factors is beyond the sea. ${ }^{91}$ Finally, Harrison used the term "necessary parties," apparently the first time it was used by a text-writer.

Two other writers on Chancery practice appeared in print at the end of this period, just before the indispensable party rule emerged. John Mitford, later Lord Redesdale, wrote the first edition of his treatise in 1782. This edition, a far briefer treatment than the second and justly renowned edition, ${ }^{93}$ seems to have played no part in developing the trend of thought manifested by Gilbert's work. Mitford recoguized the exceptions to the necessary party rule, made no mention of the "regular" decree or of active and passive parties, and confined himself to a narrative on the decided cases. ${ }^{04}$

The remaining writer was Robert Hinde, whose Modorn Practice of the High Court of Chancery was published in 1786. He gave a general statement of the necessary party rule, followed by a series of more or less disconnected case squibs, much in the manner of the writers before Mitford..$^{95}$ In a passage that with minor changes is taken from Gilbert, 96 Hinde reiterated the idea of doing "complete" justice.

90. 1 Harrison, The Accomplished Practiser in the High Court of Chancery ch. I, at 2 (1st ed. 1741).

91. 1 id. ch. I, at 2,4 . Harrison also gives "squibs" of cases involving class suits and situations, such as a suit by a specific legatee for his legacy, in which it had been held that all interested parties need not be joined. $1 \mathrm{id}$. ch. $\mathrm{I}$, at 3 .

92. 1 id. ch. I, at 6 .

93. See text accompanying notes 146-47 infra.

94. Mitford, A Treatise on the Pleadings in Suits in the Court of Chancery BY ENGLISH Bill 16, 51-53, 93 (1st ed. 1784).

95. Hinde, Modern Practice of the Higer Court of Chancerx $2-14$ (1786). There were also scattered references to the parties rules in connection with Hinde's discussions of the procedural devices by which the want of parties may be raised. Id. at $151,171,420-22$. He states the general rule as follows:

The bill must call all necessary parties, who may be affected by the demand, before the court; for if upon the face of the bill it appears that any whose right or interest are concerned, or who ought to have been, are not made parties thereto, the defendant may demur to such bill; or if he does not, yet the court, upon hearing, will not, for want of them, proceed to a decree; or if it does, the decree may be reversed; or if it be not reversed, yet none but such as were parties to the suit, and those claiming under them, can be bound by the decree.

Id. at 2. Almost the entire passage is taken from Boraun, op. cit. supra note 57, at 459-60. See text accompanying notes $57-58$ supra. The same formulation is repeated in HINDE, op. cit. sucpra at 420 .

96. Id. at 420-21:

Where it appears to the court that a very material party is wanting, without 


\section{Tae Indispensable Party Rule}

\section{A. Introduction}

We have seen that until about 1780 the Court of Chancery had adhered with substantial consistency to what is presently known as the necessary party rule: all persons interested in a controversy should be made parties unless joinder is impossible or imconvenient. It was against this background of settled practice that the indispensable party rule emerged. The rule rests on the principle that a court should do "complete" justice or none at all. Such a principle is not only incompatible with the principles previously established, but is also impossible to follow in any workable system of judicial administration. The legacy of confusion and frustration inhering in the indispensable party rule must be laid to this quixotic quest. To compound the confusion, other decisions adhered to the old principles.

For the purpose of clarity, but at the risk of chronological discontinuity, the cases adhering to the old rules will be described first; those announcing the new doctrine of indispensability will be discussed thereafter.

\section{B. The Old Rules}

Banister v. Way ${ }^{97}$ involved a creditors' bill to enforce a trust established by a testator for the payment of his debts; the defendants objected that the heir at law, who plaintiffs alleged could not be found, should be joined lest he later claim against the trustees that the will was invalid. The court, noting that the will was proved by attesting witnesses, said that the will was sufficiently established and "the heir at law, when he should appear, must get rid of it as he could."98 This seems to be a weighing of the interests of the plaintiff creditors in receiving payment against the interests of the defendants in avoiding double liability, the outcome being determined by evidence indicating that defendants' risk would be small. ${ }^{.0}$

which no complete decree can be made; as where [describing various necessary party situations, taken from the decided cases] . . . . In these and all other cases, where the decree cannot be made uniform and complete, for as on the one hand, the court will do the plaintiff right, so on the other hand they will take care that the defendant is not doubly vexed, he must not be left under precarious circumstances, because of the plaintiff, who might have made all proper parties at first, and whose fault it was that it was not so done.

Compare Gilbert's statement quoted in text accompanying note 86 supra.

97. 2 Dick. 599, 21 Eng. Rep. 404 (Ch. 1782).

98. Ibid.

99. This is another instance in which postponement of the parties question until resolution of the merits permitted a sounder disposition of the former. See note 68 supra and accompanying text. See also Brown v. Dowthwaite, I Madd. 446, 56 Eng. Rep. 164 (Ch. 1816) (in bill to recover property from an executor, residuary legatees need not be joined); Williams v. Whinyates, 2 Bro. C.C. 399, 29 Eng. Rep. 224 (Ch. 1788) (creditor's bill against executrix for payment of debts out of land charged for that purpose; heir, abroad, need not be joined). When necessary parties were amenable to process, their joinder, of course, continued to be required. See Parsons v. Neville, 3 Bro. C.C. 365,29 Eng. Rep. 586 (Ch. 1791); Sherrit v. Birch, 3 Bro. C.C. 229, 29 Eng. Rep. 505 (Rolls 1791). But see Wainright v. Waterman, 1 Ves. Jun. 311, 
Weymouth $v$. Boyer, ${ }^{100}$ decided in 1792 , is especially interesting because of its complex facts and the interesting arguments of counsel. The facts must be stated in some detail. An American mercantile partnership was in debt to plaintiff. By agreement with plaintiff, the partnership delivered tobacco to $F$, an English factor, to sell the tobacco, the proceeds to go to plaintiff to the extent of his debt, the balance to be remitted to the partnership. $F$ sold the tobacco but retained the proceeds, claiming the partnership owed him an amount in excess thereof. Plaintiff brought his bill against $F$ and one of the American partners, who was in England at the time. The other partner was alleged to be in Philadelphia and hence not amenable to process. The defendant $F$ contended the American partner had to be joined.

John Scott, later Lord Eldon, appearing for defendant, argued:

[The absent partner] is charged to be out of the kingdom: but that is neither proved nor admitted: and even if that is the case, he is a necessary party. There are many instances, that causes must be stopped, if necessary parties cannot be got to appear. A joint owner of this property has such an interest in the account, that they cannot go on without him. So in cases of mortgage, where persons have an interest, causes are often obliged to stand over; and if such parties will not put in their answers, it is unfortunate; but the Court cannot go on. . . . All persons interested must be before the Court. ${ }^{101}$

It should be noted that this is precisely the argument that is always advanced in support of the indispensable party rule: the court "cannot" go on, even if it is "unfortunate." Why it can not go on is not explained.

Plaintiff's counsel was John Mitford, author of what came to be recognized as the leading English treatise on equity practice. ${ }^{102}$ Mitford's argument was very simple: "It has been determined over and over, that where one of two partners is within the kingdom, and the other is not, the Court will proceed against the one."103

Buller, J., sitting in Chancery though his regular assignment was in King's Bench, overruled defendant's objection sub silentio and proceeded to the merits. The case is, however, the plainest application of the principle that joinder of ordinarily necessary parties is excused when impossible. There were other cases in like vein. ${ }^{104}$ In one, the absentee was characterized as a

30 Eng. Rep. 360 (Ch. 1791), in which joinder was not required of parties who, it would seem, should have been joined. Perhaps joinder was excused because the absence of the unjoined parties created no problem for the scriveners. See text accompanying notes 106-113 infra.

100. 1 Ves. Jun. 416, 30 Eng. Rep. 414 (Ch. 1792).

101. Id. at 419,30 Eng. Rep. at 415 .

102. Mrrford, op. cit. supra note 94 (2d ed. 1787).

103. 1 Ves. Jun. at 421,30 Eng. Rep. at 417.

104. Thompson v. Topham, 1 Y. \& J. 556, 148 Eng. Rep. 793 (Ex. 1827) (will not established but trusts therein enforced despite absence abroad of heir at law); E.r parte Collins, 2 Cox 427, 30 Eng. Rep. 198 (Ch. 1797) (five assignees in bankruptcy, appointed by the court, deposited the bankrupt's assets in a joint account; one assignee died, another went abroad; held, the other three assignees may withdraw the account 
"mere formal party" and his joinder excused. ${ }^{105}$ This appears to be the earliest reported case in which the "formal" and "informal" classification was used as the basis of decision. This classification added little more to that decision than it has to later ones.

\section{Development of the Indispensability Concept}

Opposed to these cases were those in which the indispensability notion developed. The startling thing about this development is the way in which the idea grew from casual dictum to apparently hardened rule in the course of but a handful of decisions. Ironically, the problem started with a dilemma of the scrivener in the office of the clerk of the court.

In Lowe v. Morgan, ${ }^{108} A$ mortgaged a share that he owned in Covent Garden to $M$, who thereafter assigned it to $T$ in trust for three named persons who had advanced money to $A$. One of these three then brought a bill to foreclose his interest. Obviously, this was a case in which sound procedural principles indicated that all the creditor-beneficiaries of the mortgage should have been joined. However, it appears that the parties acquiesced in the misjoinder. The problem arose when the clerical staff was called on to prepare the decree:

[T] he Register, finding some difficulty in drawing up the decree, applied to the Lord Chancellor, who said it was a new case, in respect of their being joint tenants, and that it would be impossible for one to foreclose without making the other two parties. The cause therefore stood over for that purpose. ${ }^{107}$

without joinder of those missing) ; Windsor v. Windsor, 2 Dick. 707, 21 Eng. Rep. 446 (Rolls 1788) (suggesting that it is sufficient to name an absent but necessary person as a party and pray process against him, to be followed by sequestration and ultimately hearing and decree despite his absence).

105. Fletcher v. Ashburner, 1 Bro. C.C. 497, 28 Eng. Rep. 1259 (Rolls 1779). A testator had established a trust under which land was conveyed to trustees to sell, the income from the proceeds to go to his widow for life, then to his son and daughter, remainder to the survivor of the son or daughter. Both son and daughter predeceased the mother, and on the death of the widow a contest for intestate rights developed between the testator's heir at law, who claimed that the entrusted property remained realty and descended to him, and the personal representative of the widow, who claimed that the entrusted property became personalty and should be distributed to him. The defendant argued that the son's personal representative should be joined. "[T] ter of the Rolls was of opinion there were sufficient parties to sustain the question; that the personal representative [of the son] was a mere formal party, and that, if he thought proper to make a decree, a personal representative might be brought before the Master." Id. at 498, 28 Eng. Rep. at 1259. See also Head v. Teynham, 1 Cox 57, 29 Eng. Rep. 1061 (Ch. 1783), in which a testamentary trust had directed that the trustee sell certain property, the proceeds to be given equally to six children. Two of these children assigned their shares to an intermediate trustee for the benefit of two others of the children. In the bill brought to compel the sale, all the beneficially interested children were made parties but the trustee under the assigned shares was not. It was held that this trustee need not be joined, seemingly on the ground that he was merely a formal party.

106. 1 Bro. C.C. 368, 28 Eng. Rep. 1183 (Ch. 1784).

107. Id. at 368,28 Eng. Rep. at 1183. 
This extraordinary decision ${ }^{108}$ was followed in 1787 by Fell $v$. Brown, ${ }^{100}$ which, though dictum on the point, became the leading case on indispensability. The suit was a bill by a second mortgagee against the first mortgagee in possession for an accounting of rents and profits. The prayer was that defendant pay himself what was due on his first mortgage, then pay plaintiff the balance on his second mortgage and, if the rents and profits were insufficient for these purposes, that the property be sold and the proceeds appropriately applied. Plaintiff alleged that the mortgagor was dead and that his heir, who should ordinarily be made a party in his place, was in America.

Defendant argued that the heir should be joined, for unless joined he would not be bound by the accounting and might subject the defendant to later suit and perhaps double liability. Plaintiff replied that if defendant's objection were sustained, plaintiff would in effect be deprived of any remedy at all. Both arguments, of course, were correct, and posed the problem that had previously been met by balancing the equities of the respective parties. Lord Chancellor Thurlow met the problem otherwise:

It seems impossible to me [to proceed] ... . without making the mortgagor or his heir a party. I admit the distinction has been taken as to proceeding in the absence of parties abroad, between their being active or passive parties, but the principal difficulty is, whether I can call the heir of the mortgagor a passive party. The natural decree is, that the second mortgagee shall redeem from the first mortgagee, and that the mortgagor shall redeem from him or stand foreclosed. I never remember a case where the decree has not been so perfected . . . .110

It is interesting to note that Thurlow first attempts to solve the problem by classifying the absent heir as active or passive. If this distinction had any meaning, it was as a basis for determining what absentees would be bound by the judgment, not what absentees had to be joined. ${ }^{111}$ Furthermore, and here we have the benefit of hindsight, this classification more accurately describes the situation of parties after a decree has been entered-the res judicata effect of a decree-rather than the situation of those whose joinder is demanded so that they may be parties to the suit.

It appears from Thurlow's language, however, that the classification problem was not his primary concern. He was really concerned with the

108. It is difficult to see why it was "impossible" to prepare the decree. In the prior cases in which joinder of necessary parties had been excused the same problem must have arisen and there is no suggestion that it had proved impossible or even difficult for earlier clerks to frame a decree disposing of only those interests before the court. Moreover, in Montgomerie v. Bath, 3 Ves. Jun. 560, 30 Eng. Rep. 115 (Rolls 1797), involving precisely the same situation as Lowe v. Morgan, a decree was entered at the suit of a partial mortgagee.

109. 2 Bro. C.C. 276, 29 Eng. Rep. 151 (Ch. 1787).

110. Id. at 278, 29 Eng. Rep. at 153.

111. See the discussion of Attorney General v. Baliol College in text accompanying notes 73-81 sipra. 
fact that the decree could not be "perfected." He said that the "natural" decree in such situations would entirely dispose of the case and complained that this could not be done in the instant case. Of course it couldn't. It never can when absentees are involved. The question has always been whether the court will nevertheless do what it can, even if this means that a "perfect" decree will not issue.

The lamentable fact is that the whole discussion was really beside the point, for as the reporter observed, "It being suggested that the heir was expected to be soon in England, Lord Chancellor ordered the cause to stand over."112

The phantasy generated in Fell v. Brozen was applied in other situations, sometimes with incredible results. ${ }^{113}$ In Palk $v$. Clinton, ${ }^{114}$ involving the same fact situation as Fell v. Brown, the Master of the Rolls said that Fell $v$. Brozen "appears to be a rule of long standing; for in Lord Nottingham's Manuscripts I see a case, Woodcock v. Mayne, in which it was held, that a second incumbrancer could not file a Bill to redeem prior incumbrancers without the mortgagor. . . ."115 The Master failed to recognize that the mortgagor was amenable to process in Woodcock v. Mayne, but not in the case before him. ${ }^{110}$

112. 2 Bro. C.C. at 279, 29 Eng. Rep. at 153.

113. In Ray v. Fenwick, 3 Bro. C.C. 25,29 Eng. Rep. 387 (Ch. 1789), the defendant gave a bond to $X$, who assigned it to plaintiff. $X$ died, his estate not being administered. Plaintiff sought ne exeat against defendant until plaintiff could obtain administration of $X$ 's estate and thus join the administrator in a suit against defendant. The relief by way of ne exeat was refused because the suit, without a representative of the original obligee of the note, must be dismissed for want of "parties"! Cf. Roveray v. Grayson (Ex. 1790), noted by Swanston in his report of Blackburn v. Jepson, 3 Swans. 132, 145 n. (b), 36 Eng. Rep. 802, 810 (Ch. 1818). See also the other cases noted therein by Swanston. For a discussion of Swanston, who was regarded as a very able reporter, see 13 HoLnsworTH 440 (1952).

In Moffat v. Farquharson, 2 Bro. C.C. 338, 29 Eng. Rep. 189 (Rolls 1788), it was said that one of several owners of a ship could not sue on behalf of himself and all others similarly situated for profits due the ship. This statement, which seems to have been dictum, was at variance with the earlier rulings in Chancey v. May, Prec. Ch. 592, 24 Eng. Rep. 265 (Ch. 1722), see note 50 supra, and Leigh v. Thomas, 2 Ves. Sen. 312, 28 Eng. Rep. 201 (Rolls 1751), see note 50 supra, and with the later case of Good v. Blewitt, 13 Ves. Jun. 397, 33 Eng. Rep. 343 (Rolls 1807) (bill for an accounting by master of ship on behalf of crew against prize agents).

One case is difficult to appraise. In Anonymous, 1 Ves. Jun. 29, 30 Eng. Rep. 215 (Ch. 1789), a motion was made to have title deeds, which had been brought before the court, delivered to a devisee. The heir at law was not a party to the proceeding. The motion was denied by Thurlow: "All parties having an apparent right, as an heir at law, must be brought into Court, before the Court will do any thing, which may affect their right: otherwise I might order these deeds to be delivered up to a party having no right." Id. at 29, 30 Eng. Rep. at 215 . The tone of this language is similar to that used in Fell $v$. Brozen, suggesting that the court will not do anything if it can not make a perfect and complete decree. On the other hand, the case seems properly interpreted as a recognition that the practical consequences of a decree, as distinct from its res judicata effects, may be highly important to absentees. In the days before recording, and when fraud and chicanery in family property affairs were by no means rare, it was a serious step indeed to commit the title deeds to the hands of a hostile or unreliable person. Cf. note 183 infra.

114. 12 Ves. Jun. 48, 33 Eng. Rep. 19 (Rolls 1805).

115. Id. at 59, 33 Eng. Rep. at 23.

116. See text accompanying notes 25-28 supra. 
The rule continued to plague the English courts. Despite Lord Eldon's attempt to return the necessary party rule to its true and ancient course, ${ }^{117}$ Chancery simply refused to untie its hands in dealing with mortgage redemption cases. In Farmer v. Curtis, ${ }^{118}$ an 1829 case, the defendant, objecting to a failure to join the heir of the mortgagor in a situation identical with Fell v. Brozen, relied on that case and Palk v. Clinton and said, "The rule may be inconvenient or absurd, and may require the interference of the Legislature; but the settled doctrines of the Court are not to be overturned on a mere allegation that the rule may be inconvenient."110 The objection was sustained. Similar objections, leading to equally "inconvenient" and "absurd" results, were sustained in later cases. ${ }^{120}$

117. In Cockburn v. Thompson, 16 Ves. Jun. 321, 33 Eng. Rep. 1005 (Ch. 1809), Lord Eldon, citing many cases, made what is generally regarded as the classic statement of the necessary party rule:

The strict rule is, that all Persons, materially interested in the Subject of the Suit, however numerous, ought to be partics: that there may be a compleat Decree between all Parties, having material Interests: but that, being a general Rule, established for the convenient Administration of Justice, must not be adhered to in Cases, to which consistently with practical Convenience it is incapable of Application. Accordingly there are several well known Cases of Exception; and, without going through them all, I will mention one Instance . . . viz. where it has been held sufficient to bring before the Court the first Person, having an Estate of Inheritance. . . . The same Principle in a great Variety of Cases has obliged the Court to dispense with the general Rule as to Persons, out of its Jurisdiction; and there are many Instances of Justice administered in this Court in the Absence of those, without whose Presence, as Parties, if they were within the Jurisdiction, it would not be administered; as it obviously cannot be so compleatly, as if all Persons interested were Parties: but the Court does what it can.

Id. at 325-36, 33 Eng. Rep. at 1007. See also Lord Redesdale's dictum in Smith v. Hibernian Mining Co., 1 Sch. \& Lef. 238 (Ir. Ch. 1803):

The ordinary practice of Courts of Equity in England when one party is out of the jurisdiction and other parties within it, is, to charge the fact in the Bill, that such person is out of the jurisdiction, and then the Court proceeds against the other parties, notwithstanding he is not before it. It cannot proceed to compel him to do any act, but it can proceed against the other parties, and if the disposition of the property is in the power of the other parties, the Court may act upon it.

$I d$. at 240 . This, it should be noted, is a proper applieation of the concept of a passive party - one who, while absent, has property interests that may be disposed of by a decree directed to those having management or control. The concept is in substance the same as the modern idea of an in rem proceeding.

118. 2 Sim. 466, 57 Eng. Rep. 862 (Ch. 1829).

119. Id. at 467,57 Eng. Rep. at 863.

120. In Browne v. Blount, 2 Russ. \& My. 83, 39 Eng. Rep. 326 (Rolls 1830), the plaintiff sought to collect a judgment against $X$, the beneficiary of a trust. Plaintiff named as defendants the trustees, the other beneficiaries of the trust and the holders of claims against the trust. Plaintiff did not join the judgment debtor, alleging that he was abroad and had been for many years. Defendant objected to his absence, citing Fell v. Brown and Farmer v. Curtis. Plaintiff cited an array of cases-Smith v. Hibernian Mine Co., 1 Sch. \& Lef. 238 (Ir. Ch. 1803), discussed in note 117 silpra; Walley v. Walley, 1 Vern. 484, 23 Eng. Rep. 609 (Ch. 1687), discussed in text accompanying notes 41-43 supra; Darwent v. Walton, 2 Atk. 510, 26 Eng. Rep. 707 (Ch. 1742 ), discussed in text accompanying notes 65-66 supra; and others-and argued that the "debtor himself was merely a formal and passive party ...." 2 Russ. \& My. at 83, 39 Eng. Rep. at 326. But it was all to no avail, as the court ruled: "[The absentee] being the person whose interests were sought to be affected by the decree, the suit could not proceed in his absence." Id. at 85 , 39 Eng. Rep. at 326 . Plaintiff might also have cited Attorney General v. Baliol College, 9 Mod. 407, 88 Eng. Rep. 538 (Ch. 1744), discussed in text accompanying notes 73-81 stpra, but it may well be doubted that it 
The doctrine of Fell v. Brown quickly passed into American procedural law. The problem of necessary parties and the new rule of indispensable parties were of special importance in the federal courts. This was so partly because not all states had equity courts at the turn of the eighteenth century, so that the questions would most likely arise in federal courts, and partly because the federal decisions were more completely reported, so that they were destined to have greater precedent value. The principal reason for the acuity of the necessary parties problem in the federal courts, however, was that the necessary party rule ran afoul of the diversity requirement of federal jurisdiction. ${ }^{121}$ The purpose of the necessary party rule was to obtain joinder of all interested persons, with a view to complete determination of the controversy; at the same time, the diversity limitation on federal jurisdiction prevented the joinder of persons who, though interested, were not of properly diverse citizenship. ${ }^{122}$ This collision between procedural objective and constitutional limitation had a distorting effect on the parties rules and made it perilous to undertake to formulate coherent parties rules.

These difficulties were accentuated by the failure of the early American judges and writers to recognize that the doctrine of Fell v. Brown was a recent innovation and, worse, by an uncritical reading of Fell v. Brown. Out of this background grew the hardened tradition of indispensability that has caused so much trouble for later generations.

The first federal case dealing with the problem of necessary parties appears to have been Milligan v. Milledge. ${ }^{123}$ Suit was brought in the United States Circuit Court for the District of Georgia by the administrator of the estate of a deceased English merchant against his debtor's legatees and devisees. The bill alleged that the decedent's executors, heirs, and other devisees were either insolvent or outside the State of Georgia. Defendant's objection that they were nevertheless necessary parties was sustained by the trial court.

would have moved the court. See also In re Dunbar, 8 Ir. Eq. 71 (1845) (testator left money in bank, in the name of three trustees, interest to be paid to testator's children during minority, then principal to be distributed; children, on reaching majority, demanded principal; court refused to order money to be paid because one of the trustees, long since absent from the jurisdiction, was not joined); Smyth v. Chambers, 4 Y. \& C. Ex. 40, 160 Eng. Rep. 911 (Ex. 1840) (annuitant under a testamentary annuity assigned portion of annuity to plaintiff, who sought to collect it from testator's executors; court refused to proceed because annuitant, who was outside the jurisdiction, was not joined).

121. The federal trial courts had no general federal question jurisdiction at the time, see Hart \& Wechsler, The Federal Courts and the Federal System 39 (1953); in any event the necessary party problem in federal courts almost always arises in diversity cases, see Reed, Compulsory Joinder of Parties in Civil Actions, 55 Mrch. L. Rev. 327, 517 (1957).

122. It was settled carly that the statutory grant of diversity jurisdiction required that there be complete diversity, i.e., that no plaintiff properly joined could be a cocitizen with any defendant properly joined. See Strawbridge v. Curtiss, 7 U.S. (3 Cranch) 267 (1806).

123. 7 U.S. ( 3 Cranch) 220 (1805). The Justices sitting were Marshall, C.J., Cushing, Paterson, and Washington, J.J. 
On writ of error to the Supreme Court, the plaintiff relied on Cozeslad v. Cely ${ }^{124}$ and Darvent v. Walton.125 There is no report of an argument by the defendant in the Supreme Court, but the plea in abatement at trial contained an objection to the failure to join "all material, necessary, and indispensable and requisite parties ...."126 The colloquy in the Supreme Court between Francis Scott Key, arguing for plaintiff, and Chief Justice Marshall indicates that the court was principally concerned with whether plaintiff could look to a devisee before having exhausted his remedies against the decedent's executors. Plaintiff argued that even if he were required to so exhaust his remedies, the bill should not be dismissed for failure to join the executor. To this Marshall said, "No doubt of that. The bill might have stood over to make new parties."127

The most interesting of the early federal cases, however, is Joy v. Wirtz, ${ }^{128}$ heard on circuit by Justice Washington. ${ }^{120}$ It was in this case that Fell v. Brown was adopted, root, branch, and foliage. It seems quite likely that Justice Washington's thinking in this case, while not explicitly cited in later decisions, nevertheless was influential in making the indispensable party

124. Prec. Ch. 83, 24 Eng. Rep. 40 (Ch. 1698), discussed in note 43 supra.

125. 2 Atk. 510, 26 Eng. Rep. 707 (Ch. 1742), discussed in text accompanying note 65 supra.

126. 7 U.S. ( 3 Cranch) at 223. The source from which the defendant acquircd the term "indispensable" does not appear. Its interposition among the other adjectives quoted suggests that no special difference in meaning was intended between necessary and indispensable parties.

127. Id. at 228.

128. 13 Fed. Cas. 1172 (No. 7553) (1806), subsequent proceedings, 13 Fed. Cas. 1172 (No. 7554) (C.C.D. Pa. 1806).

129. There is an early Virginia case that might have influenced Justice Washington at the time he wrote his opinion in Joy $v$. Wirtz. This was Hunter's Ex'rs. v. Spotswood, $1 \mathrm{Va}$. (1 Wash.) 145 (1792), in which Washington appeared for plaintiff and Marshall appeared for defendant. So far as relevant here, the case involved a suit to reach the assets of a debtor, Campbell, who had left the state. The suit was commenced by publication under a Virginia statute allowing garnishment of assets of departed debtors. On appcal, Marshall, who represented the defendant charged with having the debtor's property, argued that the decree below was invalid because it did not appear that the required publication had been made, saying "[The absentee] was no party to the suit: and therefore a decree, against persons called upon to pay his money, would be as improper, as if he had been personally decreed to pay it." Id. at 149. To this, Washington replied that "no person could take advantage of this omission but Campbell, who had not appcaled." Id. at 150 . The court nevertheless ordered the decree reversed, so that the record could show whether the publication had been made. When this was made to appear, the decree was affirmed.

At first blush, this looks like an indispensable party case and Justice Washington could well have so remembered it. However, it seems clear that the real point was that a garnishee can properly raise objections to the publication against his debtor, lest he not have a valid judgment on which to base a defense should the debtor later sue for return of the garnished property. In this light, the objection that the publication was improper goes to the adequacy of the process that is the basis of the defendantgarnishee's ozen liability to pay over the debtor's funds. At any rate, this seems to be the interpretation of the case by later Virginia cases. See Craig v. Sebrell, 50 Va. (9 Gratt.) 131 (1852); Gibson v. White, $17 \mathrm{Va}$. (3 Munf.) 94 (1812). Both these cases also involved the Virginia garnishment statute. Hunter's Ex'rs v. Spotswood has never been cited, so far as I can determine, for such a broad proposition as the indispensable party rule. 
concept a rule of the Supreme Court. ${ }^{130}$ In any event, the case is the archetype, in problem, decision, and language, of the hundreds of indispensable party cases that have since appeared.

In Joy $v$. Wirtz, a number of creditors had executed a release of their claims against the defendant debtor. A bill was brought, initially by only two of the creditors, to set aside the release on the ground of mistake. Defendant's objection that all of them should have joined was sustained by Washington, in the following language:

Where the creditors are to be paid out of a particular fund, or are united in the same transaction, so as to produce a privity between them, all are to join; and the defendant shall not be obligated to litigate the same question with each separate creditor. ... The object of the bill, is to set aside this release, which affected all the creditors equally, and in which they are all united. The Court cannot set it aside, in respect of part of the creditors, and leave it to operate against others; nor can we set it aside as to all, unless all were parties, either by name, or as being represented by a part, suing in the name of all. ${ }^{131}$

Several aspects of this opimion warrant consideration. In the first place, it has a curious combination of sound, practical reasoning - the desire to avoid a multiplicity of suits and inconsistent results-with just plain nonsense about the impossibility of setting aside the release as to some but not others. ${ }^{132}$ Second, the terminology used to describe the relation of the creditor's inter sese, "united in interest," is striking because it is precisely this term that later appeared in the Field Code to describe the conditions of required joinder. ${ }^{133}$ Third, the facts of the case were, insofar as relevant here, pre-

130. There is some similarity between Justice Washington's opinion in Joy v. Wirtz and Chief Justice Marshall's opinion in Russell v. Clark's Ex'rs, 11 U.S. (7 Cranch) 69, 98 (1912), the first United States Supreme Court case to deal squarely with the problem of a necessary but absent party. The substance of the reasoning in the two cases is the same. For a discussion of Russell $v$. Clark's Ez'rs see Reed, sipra note 121, at 347 .

For the intimate relationship between Washington and Marshall, see Custer, Bushrod Washington and John Marshall: A Preliminary Inquiry, 4 AM. J. LEGAL Hrst. 34 (1960). Washington had sat with the Supreme Court in Milligan v. Milledge, 7 U.S. (3 Cranch) 220 (1805), which was heard in February 1906, the only Term of the Court in that year, see 1 Warren, The Supreane Court IN United States History 222 (1937) ; text accompanying notes 123-127 supra. Washington first heard Joy $v$. Wirtz at his circuit's April 1806 Term and thereafter in the October 1806 Term. See 13 Fed. Cas. 1172 (No. 7553), (No. 7554) (C.C.D. Pa. 1806). On the other hand, it is not clear whether Washington participated in Russell v. Clark's Ex'rs. See 11 U.S. (7 Cranch) at 69 ("Absent-Washington, Justice"), id. at 87 ("All the judges being present" when Marshall's opinion was delivered). Professor Reed suggests the possibility of transmission of thought from Joy $v$. Wirtz to Russell $v$. Clark's Ex'rs, but does not commit himself on the point. See Reed, sipra note 121, at 347 n.66. On the basis of the meager evidence, I am inclined to think that this is probably what occurred. See Custer, supra at 45. See also the discussion of Hunter's Ex'rs v. Spotswood in note 129 supra.

131. 13 Fed. Cas. 1172 (No. 7553) (C.C.D. Pa. 1806).

132. See text accompanying note 140 infra.

133. See N.Y. Comm'rs on Practice and Pleadings, First Report 127 (1848) ("§ 99. Of the parties to the action, those who are united in interest must be joined as plaintiffs or defendants; but if the consent of one, who should have been joined as 
cisely the same as in the later Supreme Court case, Shields v. Barrow. ${ }^{\mathbf{1 3 4}}$ Finally, note should be taken of the court's clear invitation to the plaintiff to use the class suit device, an avenue of escape from the necessary partiescomplete diversity dilemma that has often since been traveled. ${ }^{135}$

The plaintiffs were given leave to amend. They did not employ the suggested class suit but instead brought suit in the name of all the creditors except one DuBois, who was alleged to be a citizen of Pennsylvania. DuBois was not joined because he was a co-citizen with defendant and could not be made a party without ousting the court's jurisdiction. In this posture, the case presented the classic indispensable party situation in the federal courtsa situation in which a choice had to be made between deviation from the joinder rules or dismissal of the action. ${ }^{136}$ It is perfectly clear that the alignment of parties presented in the amended bill was, according to the rationale of Justice Washington's first opinion, no better than that in the original bill. "All" the creditors remained just as "united" in the release as they had been before and if it was impossible to set aside the release with less than all the creditors joined in the original bill, it was just as impossible to do so with less than all creditors joined in the amended bill. Defendants promptly demurred again.

Among the many extraordinary aspects of Joy $v$. Wirtz, the most extraordinary is that Justice Washington overruled the defendant's demurrer to the amended bill. In doing so, ${ }^{137}$ he cited Fell $v$. Brown and stated what has come to be, with minor variations, the American doctrine of indispensable parties:

In deciding who ought to be parties, it is necessary to distinguish between active and passive parties; between those who are so necessarily involved in the subject in controversy, and the relief sought for, that no decree can be made without their being before the court; and such as are formal, or so far passive, that complete relief can be afforded to those who seek it, without affecting the rights of those who are omitted. The Case of Fell, 2 Brown, Ch. [Rep.] 276, presents us with the rule, and with a strong illustration of it. . . . [T] he chancellor observed, that there was a distinction as to proceeding in the absence of parties abroad, between their being active and passive: that the mortgagor, or his heir, cannot be considered as a passive party ; because, the decree is, that the second

plaintiff, cannot be obtained, he may be made a defendant, the reason thereof being stated in the complaint.") ; N.Y. Temp. Comm'n on the Courts, First Preliminary Report of the Advisory Comimitee on Practice and Procedure 237, 239-41 (1957). 134. 58 U.S. (17 How.) 130 (1854). See text accompanying note 7 supra.

135. See, e.g., Supreme Tribe of Ben Hur v. Cauble, 255 U.S. 356 (1921). See generally HART \& WECHSLER, op. cit. supra note 121, at 926-37.

136. The consequences of dismissal in Joy $v$. Wirtz. would have been especially distasteful, for the Pennsylvania state courts had no equity side at the time and the creditors therefore would have had only the uncertain remedy of attempting to obtain equitable relief in an action at law. See Fisher, The Administration of Equity Through Common Law Forms, 1 L.Q. Rev. 455 (1885).

137. 13 Fed. Cas. 1172 (No. 7554) (C.C.D. Pa. 1806). 
mortgagee shall redeem the first, and that the mortgagor redeem him, or stand foreclosed on this account; the mortgagor or his heir, being an active party, the court cannot proceed without him ; and his being a party cannot be dispensed with, though he is not amenable to the process of the court. Many other cases might be mentioned, equally strong with that just cited; and, in all of them, the rule is so stubborn, that I doubt, if, under any circumstances, it can be made to bend to the plea of necessity. But, if a decree can be made without affecting the rights of a person not made a party, or without his having any thing to perform necessary to the perfection of the decree; reason, as well as adjudged cases, will warrant the court in proceeding without him, if he be not amenable to the process of the court....138 (Emphasis added.)

Washington then analogized, correctly it would seem, the case of the English suitor beyond the seas to the American suitor who could not be joined in a federal court without destroying diversity. In a sense, neither is "amenable to the process of the court." Finally, Washington added that "the court will take care to make no decree to affect Mr. DuBois . ..."139

At the risk of taxing the reader's patience, the quotation from Joy $v$. Wirtz has been substantial. But this decision is the hinge on which the indispensability doctrine turns in American law. With due deference to the abilities of Justice Washington, it must be said that his opinion is utterly unsound.

In the first place, as previously pointed out, if ever there was a case in which it could be said that an absentee was indispensable, then surely DuBois was indispensable under the rationale of the rule announced by Justice Washington himself. Perhaps no better proof exists of the fatuity of the rule. After stating in his first opinion that the court "cannot set [the release] aside, in respect of part of the creditors, and leave it to operate against the others,"140 Justice Washington tells us in the second case that "the court will take care to" do exactly that.

Beyond that, Justice Washington attempted to formulate the difference between necessary parties whose joinder may be excused and indispensable parties. The former, he said, are those who are passive or formal. The latter, he said, are those without whom a decree cannot be made. As indicated above, ${ }^{141}$ this is not the true distinction between active and passive or formal parties. Formal parties are those who are not joined, and who need not be joined in order to completely and effectively dispose of the litigation, but who may properly be joined so that the decree will be correct in form. ${ }^{142}$ Passive parties are those whose property is in the hands of a

138. $I d$. at 1173 .

139. Id. at 1174 .

140. See text accompanying note 131 supra.

141. See text accompanying notes 110-11 supra.

142. See note 82 sipra and accompanying text. 
custodian before the court and who can therefore be brought to account despite their absence. ${ }^{143}$ Both types are, of course, parties in whose absence a decree may be entered. There is no party whose absence prevents a decree. There are parties whose absence prevents a complete decree, but that is something quite different. ${ }^{144}$ Herein lies the fallacy of the indispensability rule.

\section{Later Developments}

\section{A. Treatise Writers}

The history of the party rules in equity after Fell v. Brown and Joy $v$. Wirtz is the story of fruitless efforts to reconcile the irreconcilable. Professor Reed has dealt with the cases. ${ }^{145}$ I should like to discuss briefly the work of the trcatise writers.

Mitford was the first to consider the problem. His second edition was printed in 1787, the same ycar that Fell v. Browen was decided. It is not clear whether his manuscript was completed before that decision, but it appears that he knew about the case. Certainly he attempted to deal with the concept embodied in the indispensable party rule:

A suit may affect the rights of persons out of the jurisdiction of the court, and consequently not compellable to appear in it. If they cannot be prevailed upon to make a defence to the bill, yet, if there are other parties, the court will in some cases proceed against those parties; and if the absent parties are merely passive objects of the judgment of the court, or their rights are incidental to those of parties before the court, a complete determination may be obtained; but if the absent parties are to be active in the performance of a decree, or if they have rights wholly distinct from those of the other parties, the court cannot proceed to a determination against them. ${ }^{146}$

It should be noted that Mitford reiterated the confusion between a court's ability to make a complete decree and its ability to make any decree at all. His footnote to the foregoing passage illustrates the sense of frustra-

143. See text accompanying notes 73-81 stupra.

144. For an early recognition of this difference, see Graham v. Graham, 1 Ves. Jun. 272, 30 Eng. Rep. 339 (Ex. 1791). This was a bill for payment of an annuity against the tenants of the charged land. The principal dispute was whether the defendants had an equitable right to withhold the annuity in satisfaction of their claims against the plaintiff annuitant. The heir at law to the charged estate was not made a party; The court observed that the defendants very "properly" waived this defect; "properly," it would seem, because the heir was, at most, interested only incidentally in the dispute. The court proceeded to observe that in order to execute fully the obligation to pay the annuity-to clean up the case in its entirety-"we should have had the heir before the Court, and the will [by which the annuity was created] established; so as to execute it in toto, and not by piecemeal." Id. at 276, 30 Eng. Rep. at 341 . But, recognizing that it could not dispose of all aspects of the case without the heir, the court proceeded to shape its decree in such a way as to secure relief to the plaintiff against the defendants, without reference to the rights and claims, if any, of the heir.

145. See Reed, supra note 121 , at 483 .

146. Mitford, A Treatise on the Pleadings in Suits in the Court of ChanCERY BY ENGLISH BILL 30 (2d ed. 1795). 
tion caused by the rule: "Hence there sometimes arises an absolute defect of justice, which seems to require the interposition of the legislature."147 One may well agree, especially with the benefit of hindsight, that a "defect of justice" often arises from application of the indispensable party rule. The remedy, however, need not be legislative; logic may help.

In Mitford's third edition, he added a footnote after the phrase, "a complete determination may be obtained," in the passage quoted above. In this footnote, he cited Attorney General v. Baliol College, ${ }^{148}$ indicating clearly that he understood that case to contain an illustration of the passive party concept. It will be remembered that the Baliol College case held that a decree against the trustees of a trust, the res of which was in England, is binding on a beneficiary absent from the jurisdiction and not joined in the suit. ${ }^{149}$ In both the second and third editions, Mitford recognized the rule that a party beyond the jurisdiction need not be joined, but he made no effort to point out the contradiction between the cases applying this exception to the necessary party rule and the doctrine of Fell v. Brozen. ${ }^{150}$ In the fourth edition, edited by George Jeremy and published in 1827, the text remained the same, but Jeremy added to the footnote containing Baliol College $e^{151}$ citations to Walley v. Walley, ${ }^{152}$ Rogers $v$. Linton, ${ }^{153}$ and Quintine v. Yard. ${ }^{154}$ In the footnote referring to the "absolute defect of justice," Jeremy added Fell v. Brown. ${ }^{155}$ In no edition of Mitford, however, were the authors able to solve the conundrum.

George Cooper wrote a book on equity practice in $1809.1^{156}$ Very skimpy on authority and drawing heavily on Mitford, Cooper's treatment underscores the transition that had been made from the older view that equity will do what it can to the view of Fell $v$. Brown that equity will act only if it can do a complete job. Cooper's statement of the general rule on parties embodied the complete decree approach ${ }^{157}$ and he only incidentally mentioned

147. Id. at 30 n. (a).

148. 9 Mod. 407, 88 Eng. Rep. 538 (Ch. 1744).

149. See text accompanying notes $73-81$ sipra.

150. MitroRd, op. cit. supra note 146, at 39,146, 220-21; id. at 30, 134, 146, 221 (3d ed. 1812).

151. Id. at 32 n.(u) (4th ed. 1827).

152. 1 Vern. 484, 23 Eng. Rep. 609 (Ch. 1687), discussed in text accompanying note 41 supra.

153. Bunb. 200, 145 Eng. Rep. 647 (Ex. 1725), discussed in note 45 supra.

154. 1 Eq. Ca. Abr. 74, 21 Eng. Rep. 886 (Ch. 1702), discussed in note 45 supra.

155. MitroRD, op. cit. supra note 146, at 32 n. (x) (4th ed. 1827).

156. Cooper, A Treatise of Pleading on the Equity Side of the High Court OF CHANCERY (1809).

157. And it is a general rule, subject to exceptions hereafter noticed, that however numerous the persons may be who are interested in the subject of a suit, they must nevertheless be all made parties plaintiffs or defendants, so that a complete decree may be made between those parties, it being the constant aim of a court of equity to do complete justice, by embracing the whole subject, deciding upon and settling the rights of all persons interested in the subject of the suit, to make the performance of the order of the court perfectly safe to those who are compelled to obey it, and to prevent future litigation.

Id. at 33. (Footnotes omitted.) 
the corollary that those who cannot be joined need not be joined. ${ }^{158} \mathrm{He}$ made no attempt to reconcile the new doctrine and the old exception.

Beames' The Elements of Pleas in Equity, written in 1818, differed from treatises before and after in that it treated the joinder rule in the oldfashioned way, as a rule of convenience in which the general requirement of joinder was not applied when the absentee could not be joined. ${ }^{150}$ Hence, Beames returned to the concepts that prevailed before Fell v. Brown, but curiously enough made no mention of that case or the ones following it. It would appear that Beames chose to avoid the indispensability notion rather than meet it.

In $1823, \mathrm{D}$. G. Lubé wrote a little book that, while adding very little to Mitford, is interesting because of the author's efforts to grapple with the inconsistency between the idea of indispensability and the rule that complete joinder is excused when impractical or impossible. ${ }^{100}$ Lubé resorted to abstraction, as is done in so many judicial opinions on necessary parties, and smothered the illogic of the cases in a blanket of terminology. The result can only be described as grotesque. ${ }^{161}$

In 1832, Charles Edwards of the New York Bar produced a formidable

158. After stating the general rule, as set forth in note 157 supra, Cooper elaborated on a number of the cases requiring joinder. Interspersed in this discussion he mentioned and cited Cowslad v. Cely, Prec. Ch. 83, 24 Eng. Rep. 40 (Ch. 1698), discussed in note 43 sipra, and Darwent v. Walton, 2 Atk. 510, 26 Eng. Rep. 707 (Ch. 1742), discussed in text accompanying note 65 sipra, and a few other cases. COOPER, op. cit. supra note 156 , at 35 .

159. Beames, The Elemients of Pleas in Equity 152-59 (1st Am. ed. 1824). This book is erroneously referred to as "Barnes" in 13 Holdswortr 576 (1952), though indexed under the correct name, id. at 723 . (1823).

160. Lubé, An Analysis of the Principles of Equity Pleading 26-27, 281-83

161. Of these several parties to the suit, some have an immediate or proximate relation through the subject of litigation; others have only an incidental or derivative interest therein: and hence they may be divided into principal and collateral. And this is a distinction useful to be kept in view, for the clear perception of the scope of the bill, and for determining who are the necessary parties to the suit.

Id. at 27 .

Thus, then, all persons whose rights are necessarily involved in the litigation before the court, are necessary parties. But their rights must flow from some relation existing between them, and the principal parties to the suit. Relations, we have seen, are either, 1st, original; or, 2 nd, derivative; or, 3rd, collateral. It is clear, that all those who are parties to the original relation, must also be parties to the suit commenced by any of them toucbing such relation, or the incidents belonging to it; unless such parties as may be passed over from remoteness of interest. . . So all derivative parties, so far as their newly acquired rights may be affected by the question between the original parties, or their acquisition of new rights may affect the original rights. So, likewise, if a derivative party commence a suit against any of the original parties, it may be necessary to bring his collaterals before the court, if their collateral rights may be endangered or called in question by the suit ....

Id. at 282-83. Lubé includes a diagram that he says explains the difference between primary, derivative, and collateral rights. The diagram is a family tree linked with a chain of conveyance and looks very much like the Split-T formation. Id. at 257. Apart from its artistic interest, it is meaningless as far as I can see. 
work on parties to suits in equity. ${ }^{162}$ Edwards had by far the best collection of cases of his time. He made practically no effort to generalize about the cases and no effort at all to resolve the indispensability puzzle. As an indexdigest of the early cases, however, his book is excellent.

Frederic Calvert, of the Inner Temple, published A Treatise upon the Law Respecting Parties to Suits in Equity in 1837. This is a truly extraordinary book. While the bulk of it is a catalogue of parties decisions, it includes a long first chapter on the general problem of necessary parties which completely surpasses in clarity and analytical acuity anything that had been written on the subject and, indeed, most of what has been written since. Calvert's discussion is too long and too intricate to be restated here. Suffice it to say that he made the following points: (1) all persons who are interested should be joined, but only those who are joined should be bound by the decree, ${ }^{163}$ unless represented by someone who is a party $;^{164}$ (2) the term "interest," used to define those who must be parties, has two different meanings-interest in the out-of-court property or transaction giving rise to the litigation and interest in the controversy before the court as defined by the prayer of the complaint; ${ }^{165}$ (3) confusion of the two meanings of interest is found in the cases, so that the courts sometimes assume that because a person is interested in the property or transaction, he must be interested in the decree and hence must be joined before a decree can be issued;166 (4) the necessary party rule is a rule of convenience and the court should do less than a complete job when it must do either an incomplete job or no job at all. ${ }^{167}$

Calvert met Fell $v$. Browen head on, though from a somewhat different direction than that taken in the present discussion of the case. Nevertheless, reflection on Calvert's points shows that he exposed the fallacy of the indispensability rule. According to his first point, one not joined is not bound. Therefore, it is absurd to speak of "affecting," in the res judicata sense, a person who is not a party. According to his second point, a person may be interested in a transaction or any specific property without being interested in the suit. Therefore, a suit can affect a transaction or property without affecting an unjoined person's interest therein. Calvert's distinction between interest in the subject matter giving rise to the litigation and interest in the suit as framed corresponds exactly to the distinction between a complete decree, disposing of all aspects of the subject matter, and an incomplete

162. Edwards, A Practical Treatise on Parties to Bills and Other Pleadings in Chancery (1832).

163. Calvert, a Treatise upon the Law Respecting Parties to Suits in EQuiTy 1-18 (1st ed. 1837).

164. Id. at 19-63.

165. $I d$. at $5-11$.

166. Id. at $12-18$.

167. Id. at $64-74$. 
decree, disposing of only some aspects of the subject matter. ${ }^{108}$ It is unfortunate that Calvert did not drive this point home more forcefully than he did. It is more unfortunate that his excellent analysis was obscured by Justice Story's more readable and vastly more popular, but vastly more confused treatment of necessary parties. In this country, at any rate, Story, not Calvert, became the leading authority.

\section{B. Justice Story}

The last of the early writers on equity procedure is, of course, Justice Story. His first edition appeared in $1838 .{ }^{169}$ A comparison of his treatment of the parties problem with Mitford's discloses that most of Story's discussion was drawn from Mitford. In fact, Story added little to it. Although he had read Calvert, he quite apparently did not grasp the thrust of Calvert's analysis. ${ }^{170}$ On the contrary, Story, without blinking, placed the old necessary party rule and the doctrine of Fell $v$. Brown side by side:

All these exceptions ... [are] governed by one . . . principle, which is, that, as the object of the ... rule is to accomplish the purposes of justice between all the parties .... Courts of Equity will not suffer it to be so applied as to defeat the very purposes of justice, if they can dispose of the merits of the case before them without prejudice to the rights or interests of other persons, who are not parties, or if the circumstances of the case render the application of the rule wholly impracticable. ${ }^{\text {I }}$ On the other hand, if complete

168. Calvert, in discussing Fell v. Brown in this connection, puts the matter quite clearly :

The question is not what is the kind of relief which, under such circumstances as the plaintiff has stated, is ustally obtained, but what is the specific relief which the plaintiff in any particular suit has actually prayed. For instance, where there have been successive mortgages, "the natural decree is, that the second mortgagee shall redeem the first, and that the mortgagor shall redeem him, or stand foreclosed." To obtain this deeree, the first mortgagee must be made a party to the suit; yet a second mortgagee may, if he chooses, pray a foreclosure against the mortgagor, and no relief against the first mortgage; by adopting such a course, he may avoid the necessity of bringing before the court the first morgagee or his representative.

Id. at 13-14. (Emphasis supplied.) (Footnotes omitted.) The quotation in this passage is, of course, from Fell $v$. Brozen. See text accompanying note 109 supra.

169. Story, Commentaries on Equity Pleadings (1st ed. 1838).

170. After stating the general rule that all interested parties must be joined, Story added a footnote, id. at 74 n.4, citing Mitford, Cooper, Palk v. Clinton (see text accompanying note 114 supra), Joy $v$. Wirtz, and some other cases. He then said:

In a recent work (Calvert on Parties to Suits in Equity), which came to my hands since this whole chapter on Parties was written, it is stated, that the true rule is, that "all persons having an interest in the object of the suit (not, all persons having an interest in the subject of the suit), ought to be made parties." Calvert on Parties, 10, 11. Whether his criticism on the language of the authorities, and of the elementary writers, is well or ill founded, it does not seem necessary here to consider, as I am not aware, that it removes a single diffculty or doubt in examining the subject of parties.

STORY, op. cit. supra note 169, at 74. Calvert's criticism was not of the "language of the authorities" but of the logic of the authorities. His reframing of the formulation of the rule was an attempt to make clear his logical critique. In Story's subsequent editions, he adopted much of Calvert's treatment of parties, but without, I think, ever grasping what Calvert was driving at. Id. at $\$ \$ 72,76 \mathrm{a}-\mathrm{b}$ ( $3 \mathrm{~d}$ ed., rev., cop., \& enl. 1844). 
justice between the parties before the Court cannot be done without other parties being made, whose rights or interests will be prejudiced by a decree; then the Court will altogether stay its proceedings, even though those other parties cannot be brought before the Court .....171

In his footnote, Story cited Cockburn v. Thompson ${ }^{172}$ and other cases; in a second footnote at the end of the quoted passage he cited Fell $v$. Brozen. In both, he cited Joy v. Wirtz. Although his ensuing discussion of the particular applications of the parties rule is long and citation-studded, he never came to grips with the inconsistencies in the passage quoted above. While he stated the rule that a party not joined is not bound, ${ }^{173}$ he was prepared to stand simultaneously on the statement, echoed by so many later cases, that unjoined parties can be "prejudiced by a decree."

Story's treatise went through ten editions in the nineteenth century and in that period was the bible on equity practice. Of particular interest for present day purposes is the fact that Story was relied on in decisions in New York ${ }^{174}$ and California ${ }^{175}$ soon after the adoption in those jurisdictions of the Field Code version of the parties joinder rules. ${ }^{178}$ These decisions are the first points in the lines of contemporary precedent in code pleading jurisdictions, ${ }^{177}$ lines of doctrine that are in part the source of present Rule 19 of the Federal Rules of Civil Procedure. ${ }^{178}$ It therefore does not seem too much to say that it was chiefly Story's prestige and influence that perpetuated the indispensable party rule and that prevented its reexamination until recent years.

\section{Conclusion}

Professor Reed has traced the development of the case law from the early nineteenth century to the present. ${ }^{179} \mathrm{He}$ has shown the endless difficulties into which the courts have been led in pursuit of the phantasy that the absence of a necessary party somehow prevents a court from proceeding to a decree. At times the courts have reached acceptable results by the simple expedient of ignoring the indispensable party rule and applying instead the older and sounder necessary party rule: all interested persons must be made parties except when it is inconvenient or impossible to require

171. Id. at 78 (2d ed., rev., cop., \& enl. 1840).

172. 16 Ves. Jun. 321, 33 Eng. Rep. 1005 (Ch. 1809) discussed in note 117 supra.

173. STORY, op. cit. supra note 169, at 77 .

174. Gray v. Schenck, 4 N.Y. 460 (1851).

175. McPherson v. Parker, 30 Cal. 456 (1863).

176. See note 4 supra.

177. See Bank of California v. Superior Court, 16 Cal. 2d 516, 106 P.2d 879 (1940) (citing McPherson v. Parker, 30 Cal. 456 (1863)); N.Y. TEMP. CoMM'N ON THE Courts, First Preliminary Report of the Advisory Committee on Practice and PROCEDURE 237, 241-42 (1957).

178. See Advisory Comm. on Rules for Civil Procedure, Rules of Civil Procedure for the District Courts, S. Doc. No. 101, 76th Cong., 1st Sess. 238 (1939).

179. Reed, supra note 121 . 
their joinder. ${ }^{180}$ But other courts have not escaped the clutch of Fell v. Brown. They apply the indispensable party rule without pausing at its illogic and with seeming indifference to the procedural consequences that flow from its application. This can be demonstrated by consideration of one of the legion of modern indispensable party cases.

In Fouke v. Schenewerk, ${ }^{181}$ the plaintiff brought an action in a federal district court for a declaratory judgment to establish his right to an interest in minerals as against the claims of four named defendants. Jurisdiction was founded on diversity, plaintiff alleging that he was a citizen of Texas and defendants were citizens of Arkansas. When defendants failed to appear, plaintiff obtained a default judgment against them. Defendants then moved to set aside the judgment, alleging and proving that some of them were citizens of Texas. The trial judge granted the motion as to the Texas defendants, but denied it as to the Arkansas defendants, ordering that the judgment to be amended to state specifically that "[the rights of the Texas defendants], if any, in the subject matter of this suit shall not be prejudiced by such amended judgment." As amended, therefore, the judgment determined plaintiff's rights as against the Arkansas defendants but stated that it in no way affected, as indeed it could not affect, the rights of the Texas defendants. The Arkansas defendants then appealed, contending that the Texas defendants were indispensable and that the court was without jurisdiction to render a judgment without joinder of the Texans.

In sustaining the defendants' contention, the Court of Appeals for the Fifth Circuit said:

It would not be possible for the court to uphold the plaintiff's contention as to the validity of this deed [under which plaintiff claimed title] without prejudicing the rights of the defendants that were eliminated by the court below in an effort to cure its lack of jurisdiction. The judgment appealed from established that deed as a muniment of plaintiffs' title, and if permitted to stand would seriously prejudice the right and title of all the defendants. ${ }^{182}$

The court did not explain how the absentees would be "seriously prejudiced." To conclude that there was such prejudice the court would be compelled to say that the judgment was binding on a person not a party to the action and whose rights were explicitly, if redundantly, reserved. Such a statement is simply not true. And if the statement is not true, it is nonsense to say that the absentee is prejudiced by the judgment. ${ }^{183}$ Hence,

180. See, e.g., Bank of California v. Superior Court, 16 Cal. 2d 516, 106 P.2d 879 (1940); Keene v. Chambers, 271 N.Y. 326, 3 N.E.2d 443 (1936).

181. See 197 F.2d 234 (5th Cir. 1952) (district court decision not reported).

182. $I d$. at 236.

183. Of course, an absent party may be prejucliced by the stare decisis effect of a decision, but surely no one will urge that all persons must be joined in a suit the decision of which may sometime serve as an adverse precedent. An absent party may 
application of the indispensable party rule resulted in depriving plaintiff of a perfectly valid remedy against one defendant for the sole reason that plaintiff could not simultaneously obtain a remedy against another defendant, i.e., because a complete decree could not be had. This is the indefensible result of the indispensable party rule.

I have attempted to show that the lineage of the indispensable party. rule is no better than its logic. Perhaps in time reason and authority will lead the courts to lay the ghost to rest.

also be prejudiced by the parties' acting in accordance with a decree or judgment, as when a fund is distributed to creditors. But this prejudice does not result from the fact that the absentee is bound by the judgment, but because the practical value of a later suit by him may be impaired by the change of out-of-court circumstances. The prospect of such impairment is indeed a factor to be considered in determining who should be joined, i.e., who are necessary parties. See Reed, supra note 125, at 336-39. But the sole fact of such impairment is not ground for refusing to proceed, any more than the fact that a debtor's payment of a judgment will impair his ability to pay otliers is ground for refusing to proceed with a creditor's suit. And in no event can such a practical impairment occur when, as in Fouke $v$. Schenewerk, the judgment is simply declaratory, not requiring or involving change in out-of-court circumstances affecting the practical position of the absentee. 